\title{
The development of a performance index for KG funds and a comparison with other shipping-related indices
}

\author{
Wolfgang Drobet $z^{a}$ and Lars Tegtmeier ${ }^{b}$ \\ ${ }^{a}$ Institute of Finance, University of Hamburg, Von-Melle-Park 5, \\ 20146 Hamburg, Germany. \\ E-mail: wolfgang.drobetz@wiso.uni-hamburg.de \\ ${ }^{\mathrm{b}}$ TKL.FONDS Gesellschaft für Fondsconception und-analyse mbH, \\ Hans-Henny-Jahnn-Weg 35, 22085 Hamburg, Germany. \\ E-mail: tegtmeier@tkl-fonds.de
}

\begin{abstract}
Despite their high economic importance, academic research has granted KG funds only marginal attention. A main reason is the lack of reliable performance data due to non-observable market prices during the lifetime of a KG fund. In order to measure the performance of KG funds, we construct an index using a database of more than 300 German one-ship companies during the sample period from December 1996 to December 2007. Looking at the distributional characteristics and the correlation structures, we analyse the comovement of the KG index with a broad set of other shipping-related indices. The variation of our index is more dependent on vessel prices than on charter rates. Moreover, we use principal component analysis (PCA) in order to examine whether there are common structures and linkages between the different indices. On the basis of the resulting factor loadings, the KG index exhibits peculiar risk-return characteristics. PCA identifies one statistical factor that is specific to KG funds in the sense that only the KG index loads significantly on this particular factor. Our index does not merely represent a linear combination of vessel prices and freight rates, and it also does not stand in direct relationship with all other shipping-related indices. Instead, it constitutes a new index concept measuring the development of the market value of equity and distributions in the form of a performance index and incorporates specific information that is primarily of importance for one-ship companies. The availability of a performance index will likely increase transparency in the market for closed-end ship funds.
\end{abstract}

Maritime Economics \& Logistics (2013) 15, 32-71. doi:10.1057/mel.2012.21

Keywords: closed-end ship fund; KG fund; performance index; risk-return profile of shipping investments; correlation analysis; principle component analysis 


\section{Introduction}

Closed-end ship funds represent an important form of capital investment for private retail investors. Private investors have contributed approximately $€ 30$ billion into closed-end ship funds since 1993 (Feri EuroRating Services AG, 2009). Likewise, they are the most important financing instruments for the German charter owners. Financing ships through the international capital markets, such as the issuance of high-yield shipping bonds (Leggate, 2000; Grammenos et al, 2007; Grammenos et al, 2008; Kavussanos and Tsouknidis, 2010) and initial public offerings (Grammenos and Arkoulis, 1999; Cullinane and Gong, 2002; Merikas et al, 2009; Merikas et al, 2010), has not been common in Germany even in the recent past. Accordingly, closed-end ship funds are 'the' financing vehicle that has substantially contributed to the development of Germany as one of the leading international centres of the maritime industry. In fact, more than 20 per cent of the international container fleet have been financed through so-called KG ("Kommanditgesellschaft") structures. Acknowledged as the notion of the 'KG fund', closed-end ship funds have established themselves as a uniquely German form of ship financing on the international markets (Clarkson Research Services Ltd., 2008). ${ }^{1}$

A KG fund represents a long-term investment in a vessel with a contract duration of 15-25 years. Its main characteristics are best described by the corporate objectives of the investment vehicle: the acquisition, the chartering and ultimately the sale of the fund vessel. German KG funds are regularly organized in the legal form of a so-called GmbH \& Co. KG, which is the equivalent of a LLP (limited liability partnership) where the entity with unlimited liability is the managing company instead of a person. They only generate cash flow from operating the fund vessel, and therefore KG funds ultimately represent an entrepreneurial participation (Friedrichs et al, 2007; Drobetz et al, 2008b).

Despite their economic importance, KG funds have been granted only minor attention. A crucial reason for this shadowy existence in the academic finance literature is the fact that investments in this asset class are difficult to incorporate into the framework of modern portfolio theory. The lack of a representative performance index for $\mathrm{KG}$ funds creates an immediate obstacle for an adequate analysis from a portfolio perspective. It is therefore the objective of our study to construct a transparent and methodologically consistent performance index for KG funds, to describe its statistical properties, and to compare the risk-return characteristics of KG funds with other shipping-related indices. The availability of a KG index is important for investors and shipowners alike. Our index allows investors to better assess the return-risk characteristics of KG funds as an asset class and their diversification benefits from a portfolio perspective. From the company perspective, our index enables shipowners to better determine their

\footnotetext{
C 2013 Macmillan Publishers Ltd. 1479-2931 Maritime Economics \& Logistics $\quad$ Vol. 15, 1, 32-71 33
} 
company's cost of capital. Although not explicitly discussed in this study, our results can lead to more elaborate capital budgeting and financing decisions. The empirical findings indicate that our KG index exhibits peculiar risk-return characteristics. Most important, principal component analysis (PCA) identifies one factor that is specific to KG funds in the sense that only our index loads significantly on this particular (statistical) factor. We conclude that the KG index incorporates specific information, which is primarily of importance for KG funds.

The remainder is structured as follows: We first provide a description of the concept of KG funds and distinguish them from alternative equity investments into ships. We proceed with the development of an index concept, which is then applied to compute a performance index for KG funds based on historical data over the sample period from December 1996 to December 2007. Finally, we discuss the return-risk characteristics of our KG performance index and compare them with other shipping-related indices.

\section{Investment Opportunities in Ships through Equity}

Apart from direct investments into ships, the shipping industry offers investors numerous opportunities in terms of equity investments. ${ }^{2}$ Investors can choose between KG funds, various shipping trust structures (such as the German Shipping AG, the Singapore Trust or open-ship funds), publicly listed shipping companies and industry-specific investment funds. Table 1 describes these investment opportunities in ships through equity and summarizes the most important differences.

\section{The nature of a KG fund}

KG funds still represent the most important type of equity investment in ships in Germany. A KG fund is an entrepreneurial investment that belongs to the category of indirect (equity) investments in the shipping industry. Figure 1 shows the typical structure of a KG fund. The fund is conceptually developed by an equity (issuing) house and offered to potential investors with the help of financial consultants (investment brokers or banks) for subscription. KG funds are regularly organized in the legal form of a $\mathrm{GmbH} \&$ Co. KG. A KG is a partnership under a legal name. There must be a minimum of two partners, at least one limited and at least one unlimited. The $\mathrm{GmbH} \&$ Co. KG is like a KG, but the entity with unlimited liability is a $\mathrm{GmbH}$ (Gesellschaft mit beschränkter Haftung), which itself is a company with limited liability instead of a person. The investor joins the KG fund directly as a limited partner on the basis of a shareholder contract or indirectly through a trust company based on a trust 
Table 1: Equity investments in the shipping industry

\begin{tabular}{|c|c|c|c|}
\hline & $K G$ funds & $\begin{array}{l}\text { Shipping trusts } \\
\text { (e.g., German Shipping } \\
\text { AG, Singapore Trust, } \\
\text { open funds) }\end{array}$ & $\begin{array}{l}\text { Listed shipping } \\
\text { companies }\end{array}$ \\
\hline $\begin{array}{l}\text { Business purpose } \\
\text { and legal structure }\end{array}$ & $\begin{array}{l}\text { Purchase, operation and } \\
\text { sale of one or more } \\
\text { ships. GmbH \& Co. KG is } \\
\text { an investment company } \\
\text { and owner of the ship. } \\
\text { Investor is limited } \\
\text { partner (directly or via } \\
\text { trustee). }\end{array}$ & $\begin{array}{l}\text { Purchase, operation and } \\
\text { sale of ships. Investor } \\
\text { is shareholder of a } \\
\text { stock corporation or } \\
\text { investment company } \\
\text { with variable capital } \\
\text { (SICAV), which is } \\
\text { indirectly owner of the } \\
\text { ships via the one-ship } \\
\text { companies. }\end{array}$ & $\begin{array}{l}\text { Investor is } \\
\text { shareholder of a } \\
\text { stock corporation. } \\
\text { Operating business } \\
\text { concentrates partly } \\
\text { or entirely on the } \\
\text { shipping and/or } \\
\text { transportation } \\
\text { industry. }\end{array}$ \\
\hline Capital & $\begin{array}{l}\text { Fund is closed after the } \\
\text { required money has } \\
\text { been raised. }\end{array}$ & $\begin{array}{l}\text { Open capital increase; } \\
\text { fund volume is not } \\
\text { limited. }\end{array}$ & Open capital increase \\
\hline Liquidity & $\begin{array}{l}\text { Low in the past, slightly } \\
\text { increased through the } \\
\text { creation of secondary } \\
\text { markets }\end{array}$ & $\begin{array}{l}\text { Daily tradeable or } \\
\text { repurchase obligation } \\
\text { of the investment } \\
\text { company (with delay, if } \\
\text { necessary) }\end{array}$ & Daily tradable \\
\hline Diversification & $\begin{array}{l}\text { No diversification of } \\
\text { one-ship funds, } \\
\text { diversification in fund } \\
\text { of funds }\end{array}$ & $\begin{array}{l}\text { High diversification by } \\
\text { owning various ship } \\
\text { types and ship sizes }\end{array}$ & $\begin{array}{l}\text { Depends on the fleet } \\
\text { of the firm }\end{array}$ \\
\hline Cost structure & High & Low & Low \\
\hline Investor structure & Private investors & $\begin{array}{l}\text { Institutional investors } \\
\text { and wealthy private } \\
\text { investors }\end{array}$ & $\begin{array}{l}\text { Institutional investors } \\
\text { and private } \\
\text { investors }\end{array}$ \\
\hline
\end{tabular}

deed. The fund forms a one-ship company and serves as the financing and liability vehicle. Moreover, KG funds are financed using a mixture of equity and debt capital. The necessary debt capital is provided by a ship-financing bank to the one-ship company in form of a ship mortgage loan, which usually amounts to about 60 per cent to 70 per cent of the vessel price. Within certain limits, the investors can delegate monitoring and decision-making rights to a supervisor (or advisory council).

During the start-up phase, the fund consists of a general partner and one or more founding limited partners, who in most cases belong to the issuing house. In the course of the successive joining of investors to the one-ship company, one or all limited partners withdraw. The fund is closed as soon as the share capital has been fully raised. The general partner remains as a personally liable partner in the one-ship company and receives a liability fee. However, the peculiar feature of a $\mathrm{GmbH} \& \mathrm{Co}$. KG is that the general partner is itself a $\mathrm{GmbH}$, hence a company with limited liability. If the financing object is a new ship, the shipyard

(C) 2013 Macmillan Publishers Ltd. 1479-2931 Maritime Economics \& Logistics Vol. 15, 1, 32-71 35 


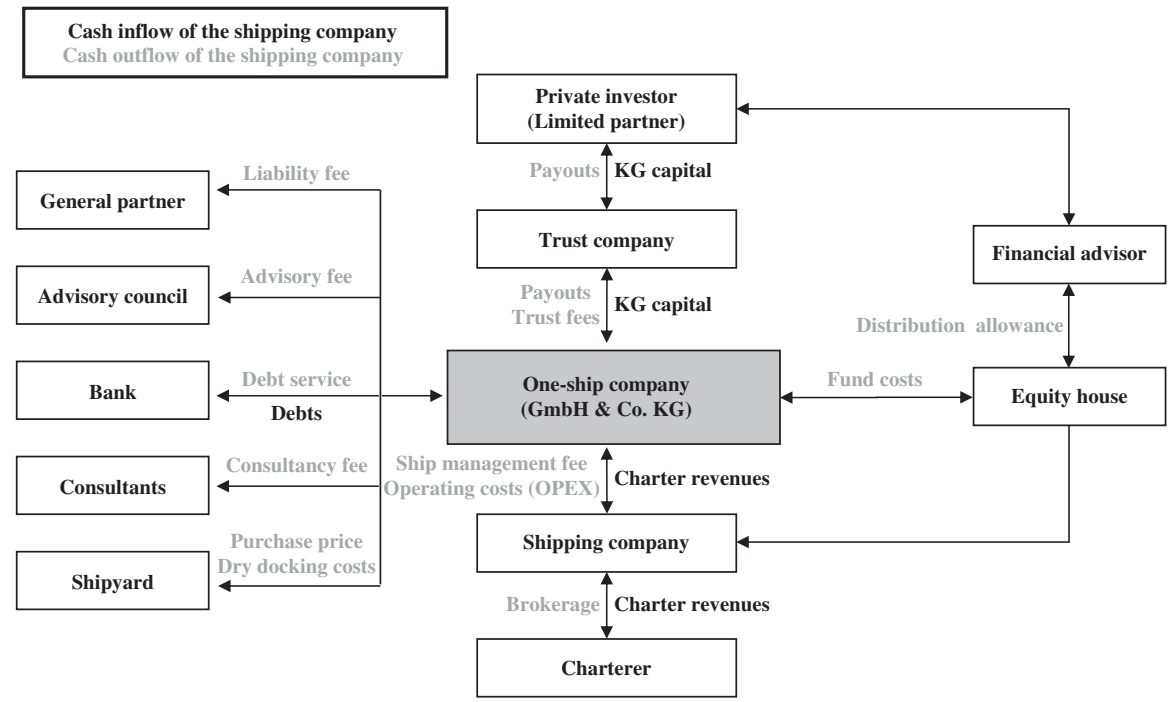

Figure 1: Structure of a KG fund.

will deliver it to the one-ship company, which generally provides long-term charter coverage. Furthermore, the one-ship company signs a management contract with a ship-management company in order to carry out all technical and commercial management duties required by the charterer. Lawyers, accountants and shipping experts are also regularly involved as external consultants.

Although KG funds represent an attractive type of investment for private investors in order to diversify their portfolio (Tegtmeier and Topalov, 2006), they might be less suitable for institutional investors. The 'soft costs' of KG funds, which are often higher than the direct costs of an IPO, are one reason why institutional investors tend to be reluctant to invest in KG funds. Moreover, their extremely long investment horizon and their non-tradability do not meet the liquidity requirements of institutional investors. To some extent, the recent introduction of secondary market platforms has alleviated these disadvantages of KG funds (Drobetz et al, 2008a). Another drawback is that the investor cannot exploit market fluctuations of freight rates and vessel values because the cash flow of a KG fund is usually fixed based on a long-term charter contract. The 'true' value of the investment is only known (ex post) after the fund's liquidation, and thus a regular valuation of the asset in an institutional investor's portfolio is difficult.

\section{Listed shipping companies and new asset management products}

An alternative opportunity for participation in the shipping industry is an investment in shares of publicly listed companies. ${ }^{3}$ Even if publicly listed 
shipping companies represent only a relatively small investment segment, which has been particularly affected by the current financial crisis due to the cyclical nature of the shipping markets, IPOs have developed into an important alternative to cover the increased capital requirements in the shipping industry over the last few years (Albertijn et al, 2011). In fact, the global new issuing volume (including both IPOs plus capital increases) has grown rapidly from $\$ 300$ million in the year 2000 to around $\$ 17$ billion in the year 2007. However, the issuing volume plummeted to only $\$ 2$ billion in the year 2008 (Maritime Services, 2009). A caveat is that the shares of publicly listed shipping companies do not always represent a pure investment in ships. For example, in contrast to most of the US-listed Greek shipping companies, diversified logistics companies tend to have broader business objectives than investing in ships and primarily obtain their revenues from the transportation of freight. Furthermore, shipping represents only one line of business for many publicly listed companies. Consistent with this observation, Kavussanos et al (2003) show that the stock market beta of publicly listed shipping companies is dependent on the amount of revenues in the shipping industry relative to total revenues.

Another issue to consider when implementing an IPO is that conflicts of interest between the old owners and new shareholders can arise (Randoy et al, 2003; Syriopoulos and Theotokas, 2007; Lambertides and Louca, 2008). Investors frequently express concerns about high expenditures due to burgeoning organizational structures, their limited control rights (corporate governance deficits) and possible deviations of the market valuation from the net asset value. Therefore, new asset management products have been developed during the last years, which are based on trust structures and cover an array of fungible investment vehicles, such as the German Shipping AG, the Singapore Trust, the US Master Limited Partnership and open-ship funds. These alternative IPO vehicles are structured around an open-end collective investment scheme, where the investment company (SICAV) is indirectly the owner of the vessel through a one-ship company. Accordingly, shipping trusts are listed in Table 1 between KG funds and publicly listed shipping firms.

A shipping trust distinguishes between shareholders and the trust manager. The trust manager is responsible for building up a diversified ship portfolio and for achieving stable profits for the shareholders from chartering out the vessels. Resembling a KG fund, shipping trusts generate their cash flow from operating ships. The operating cash flow generated by the trust vessels can be distributed to shareholders as a tax-free dividend, and shareholders' returns are determined by the amount of the payout rather than the realization of capital gains. This feature of a shipping trust is an essential advantage over a 'normal' publicly listed shipping company in which only (after tax) accounting profits are eligible for distribution.

Unlike KG funds, both shipping trusts and publicly listed shipping companies can pursue asset play strategies. While some trusts build up a diversified

(C) 2013 Macmillan Publishers Ltd. 1479-2931 Maritime Economics \& Logistics $\quad$ Vol. 15, 1, 32-71 37 
ship portfolio based on a simple business model that operates the trust vessels passively on the basis of long-term charter contracts ( $>10$ years), other trust structures pursue active asset management strategies. A listed shipping company can employ its ships in the spot market and gain additional profits by actively timing the buying and selling decisions of vessels. A less active trust strategy with lower cash flow volatility may focus on a certain sector of the shipping industry (for example, the container sector) and employ the ships based on short-term charter contracts (2-3 years) in a shipping pool in order to diversify risks. In contrast, KG funds always pursue a passive buy-and-hold strategy because selling the vessel immediately leads to the liquidation of the fund. Another difference between trust structures and a closed-end fund is that trust shares, just like shares of publicly listed shipping firms, are traded on organized exchanges. Open-fund structures guarantee the repurchase of shares by the investment company. However, the repurchase is usually carried out with some temporal delay and is restricted to an upper limit.

In spite of the manifold investment opportunities into ships through equity, there is a comparatively low number of benchmarks in the form of adequate (and investable) shipping indices. In fact, there exist only a few indices of publicly listed shipping firms, such as the Clarkson Liner Share Price Index and the Clarkson Tanker Share Price Index. This lack of appropriate benchmarks is a reason why the asset class 'ships' - and particularly KG funds - have not been analysed in a broader portfolio context. Due to data availability, empirical studies about the diversification benefits of ships as an asset class are limited to investments into stocks of publicly listed maritime firms (Grammenos and Arkoulis, 2002; Syriopoulos and Roumpis, 2009; Grelck et al, 2009; Drobetz et al, 2010). Given the economic importance of KG funds, similar analyses represent an important contribution both from a theoretical and a practical point of view. A KG index allows investors to better assess the return-risk characteristics of this asset class and its diversification opportunities. Moreover, on the basis of a KG index, shipowners are able to determine their company's cost of capital and take capital budgeting as well as financing decisions that are better grounded in financial theory. Therefore, in what follows, we present the theoretical framework and the empirical procedure to construct a transparent and methodologically consistent performance index for KG funds.

\section{Development of a Performance Index for KG Funds}

\section{Cash flow statement of a KG fund}

The requirements for a KG performance index are similar to the requirements for stock performance indices, whose goal is to document the performance of 
the index portfolio by considering all return components (total return indices). The return components of a performance index consist of stock price changes and dividend distributions, implicitly assuming that dividends are reinvested into the KG fund (Angele, 1996; Schmitz-Esser, 2001). ${ }^{4}$ Applied to a KG fund, the total return components are made up of the market value changes of the equity capital and the payouts to the limited partners of the one-ship company. In contrast to publicly listed companies, where the returns are directly observable on the market, the return components of KG funds are more difficult to measure because KG funds are regularly organized under the legal form of a $\mathrm{GmbH} \& \mathrm{Co}$. KG and therefore public data is not always available.

Figure 2 explains how the performance-related return components of a KG fund can be derived consistently from the fund's cash flow statement. The capital requirements during the investment phase of a one-ship company are determined by the sum of the purchase price of the ship, the initial fund costs and the costs of fundraising. The complete investment volume is financed using debt and equity capital. Therefore, the market value of the equity capital in $t=0$ of a one-ship company $\left(-I_{0}^{\mathrm{EC}}\right)$ is given by the total investment volume $\left(-I_{0}^{\mathrm{TC}}\right)$ minus debt. The total cash flow during the operating phase $\left(C F_{t}^{\mathrm{TC}}\right)$ is
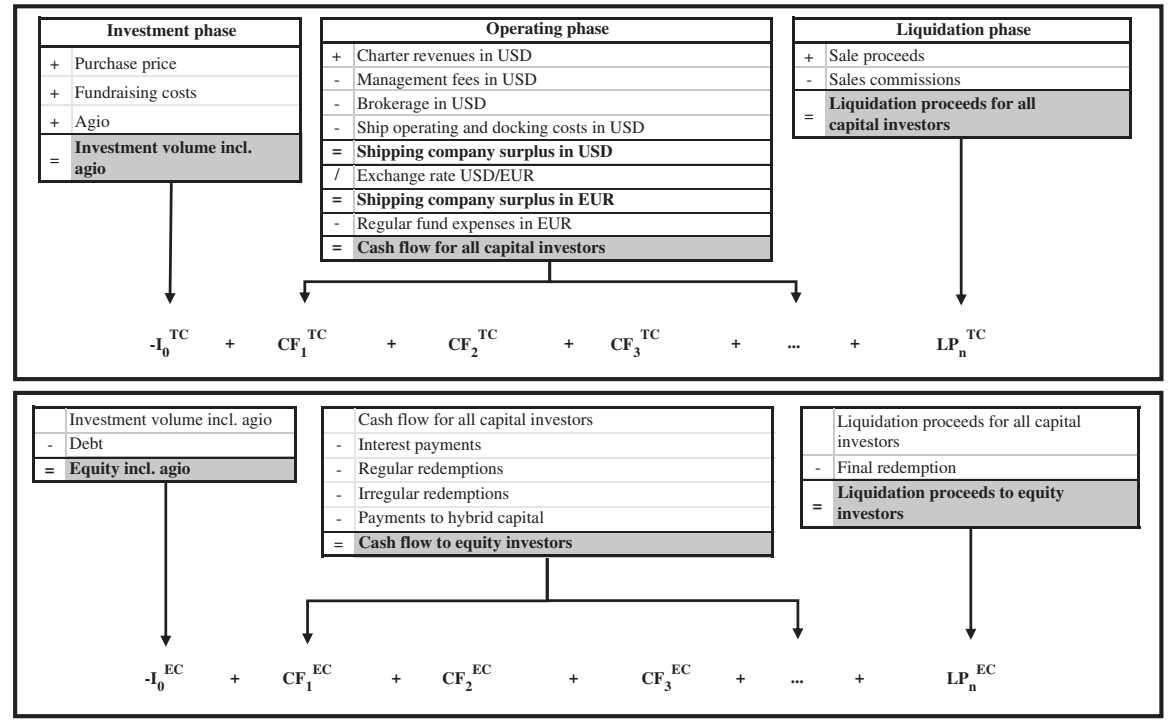

$$
\begin{aligned}
& \text { Performance components } \\
& \text { 1. } \mathbf{E C}_{\mathrm{t}}=\mathbf{M V}_{\mathrm{t}}^{\text {Ship }}-\mathbf{D C}_{\mathrm{t}}+\mathbf{L R}_{\mathrm{t}} \\
& \text { 2. } \mathbf{P}_{\mathrm{t}}=\mathbf{C F}_{\mathrm{t}}^{\mathrm{EC}}-\left(\mathbf{L R}_{\mathrm{t}}-\mathbf{L R}_{\mathrm{t}-1}\right)
\end{aligned}
$$

Figure 2: Cash flow of a KG fund. 
determined by the freight rates as well as all asset- and company-related costs. Equity investors hold a residual claim and are entitled to all cash flows that exceed the debt service payments and the payouts to investors into hybrid capital $\left(C F_{t}^{\mathrm{EC}}\right)$. This surplus can be fully distributed to investors $\left(P_{t}\right)$, or it can remain fully or partly as a liquidity reserve $\left(L R_{t}\right)$ in the one-ship company. Finally, in order to determine the investors' liquidation proceeds at maturity of the KG fund $\left(L P_{n}^{\mathrm{EC}}\right)$, the brokerage and sales commission as well as the final redemption must be deducted from the proceeds of the vessel sale.

\section{Valuation of the fund vessel}

The business purpose of a one-ship company is the acquisition, the operation and the sale of the fund vessel. Accordingly, the value of a one-ship company is primarily determined by the market value of the fund vessel. The market values of ocean-going vessels are usually assessed using standard valuation multipliers (Adland and Koekebakker, 2007; Esty and Sheen, 2010), and therefore the value of the fund vessel is determined based on a comparison with the transaction prices of similar vessels. Ship-broking companies maintain databases with prices from comparable transactions (or broker valuations). While the comparable prices refer to vessels that are free of charter contracts, the ships of KG funds are employed on a time-charter basis. Therefore, the present value of the time-charter contract must be incorporated when valuing the fund vessel (in particular, when the time-charter rate strongly deviates from the current freight rate in the spot market due to different market conditions during the course of the time-charter contract). The market value of ships with a fixed charter contract will differ from the market value of vessels without a fixed charter contract because they obtain higher or lower revenues dependent on the prevailing level of freight rates in the spot market. Therefore, the market values of ships published in vessel databases must be adjusted: ${ }^{5}$

$$
M V_{i}=M V_{j}+F V_{i}
$$

According to equation (1), the market value of the fund vessel $\left(M V_{i}\right)$ equals the realized transaction price of comparable ships $\left(M V_{j}\right)$ plus the present value of the fixed time-charter contract $\left(F V_{i}\right)$. The present value of the time-charter contract is:

$$
F V_{i}=\sum_{t=0}^{R M T} \frac{F R_{t}-M R_{t}}{(1+r)^{t / 365}}
$$

The difference between the fixed freight rate per day $\left(F R_{t}\right)$ and the market freight rate per day $\left(M R_{t}\right)$ in the numerator of equation (2) indicates how much 
more or less the vessel earns each day until the maturity of the time-charter contract compared with the current freight rate level. ${ }^{6}$ The sum of the daily differences during the remaining time to maturity (RMT) of the time-charter contract must be discounted using a risk-adjusted annual discount rate $(r)$.

The level of the future spot freight rate is unknown, and thus forecasts about the future spot freight rates until maturity of the time-charter contract are required. We make the assumption that the spot freight rate, which prevails at the valuation date, converges linearly to the expected freight rate within 5 years. Specifically, on each valuation date, the expected freight rate is the average of the prior 10-year daily freight rates (Drobetz et al, 2008b; Stopford, 2009). Due to data availability on each valuation date before 1 January 2007, the expected freight rate is the 10-year average of daily freight rates during the period from 1 January 1997 to 31 December 2006. As an alternative to historical means, statistical forecasting models could be used. However, empirical studies by Kavussanos et al (2004), Batchelor et al (2007) and Bessler et al (2008) indicate that forward freight rates provide unbiased predictions for future spot rates only for short time horizons of 2-3 quarters ahead. ${ }^{7}$ Moreover, there is no reliable empirical evidence about the quality of time series models and other long-run prediction models for freight rates. For the case of stock returns, Campbell and Thompson (2008) and Goyal and Welch (2008) show that none of the standard forecasting variables (for example, interest rate spreads) are able to beat the prediction quality of long-run mean returns. While this approach is nevertheless ad hoc, the choices of a 5-year convergence period (the adjustment speed) as well as 10-year long-run averages (the adjustment target) for freight rates (and exchanges rates; see below) do not materially affect the statistical properties of our index. ${ }^{8}$ According to Stopford (2009), historical shipping cycles (and hence freight rate cycles) averaged around 8 years. Given that we evaluate fund vessels at some point in time during their lifetime, a convergence period of 5 years seems an appropriate choice.

In some instances, time-charter contracts are closed on an EUR basis. The payments of these freight contracts must be converted into USD, which requires predictions for the future USD/EUR exchange rates. We assume that the USD/ EUR exchange rate, which prevails at each valuation date, converges linearly to the expected USD/EUR exchange rate within 5 years. Again, at each valuation date, the expected USD/EUR exchange rate is taken as the 10-year average of daily exchange rates. For all valuation dates before 1 January 2007, the expected USD/EUR exchange rate is represented by the 10-year average of the daily USD/ EUR exchange rates during the period from 1 January 1997 to 31 December 2006. International parity relationships suggest that there are fundamental relationships between exchange rates, interest rate rates and inflation rates, which should hold at least in the long-run. For example, according to the 
uncovered interest parity theory, the EUR is expected to devalue against the USD if in the long-run the interest rate level is higher in Euroland than in the United States and vice versa. However, given the findings in Fama (1984) and Engle (1996) that the uncovered interest parity must be rejected empirically (forward premium puzzle), we rely on simple historical means to proxy for the expected exchange rates.

In order to determine the present value of a time-charter contract according to equation (2), an adequate risk-adjusted discount rate is needed, which can be determined using the Capital Asset Pricing Model (CAPM) developed by Sharpe (1964), Lintner (1965), and Mossin (1966). The CAPM requires estimating adequate risk premiums for the shipping industry. First, in order to determine industry-specific market betas of listed shipping companies, which are active in the container, tanker and bulker sectors, we run firm-level market model regressions. We use industry betas because companies in a given sector exhibit similar systematic risk due to their comparable business models (Bessler et al, 2008). Second, the MSCI world stock market index is used as a proxy for the true but unobservable market portfolio.

The Clarkson Liner Share Price Index and the Clarkson Tanker Share Price Index serve as the starting point for our sample of publicly listed liner companies in the container and tanker sectors. The selection of the bulk companies is based on the Drewry Dry Bulk Insight. We also consult the Norwegian shipping industry newspaper TradeWinds. Overall, 48 stock exchange listed liner companies have been identified, of which 6 firms are active in 2 or all 3 sectors. Monthly return data is collected for the sample period from January 1996 to December 2007. Because not all firms have such a long history, we require that price data is available at least back to January 2005. Stock prices are taken from Thomson Financial Datastream and MSCI Barra; they are adjusted for payouts and stock splits. Given that the leading currency in the maritime industry is the USD (Kavussanos and Visvikis, 2006) and that shares are listed on various stock exchanges, all price data is converted into USD. We compute logarithmic monthly returns in order to run a market model regression for each sample stock. For the sake of brevity, detailed results of the individual market model regressions are shown in Appendix A. ${ }^{9}$ Given the individual stock market betas, industry betas can be computed as the average regression coefficients in the tanker, container and bulker sectors. These averages can be based on market capitalization weights or equal weights. Market capitalization weights usually lead to strong weightings of the most liquid shares, and hence it is possible that the beta is dominated by only a few shipping stocks. We thus use an equal-weighting scheme to estimate the industry beta as simple averages of the individual firm betas.

Using the approach described above, the equally weighted betas of the container, tanker and bulker sub-sectors are $1.00,0.83$ and 0.77 , respectively

(C) 2013 Macmillan Publishers Ltd. 1479-2931 Maritime Economics \& Logistics Vol. 15, 1, 32-71 
(see Appendix A). It is clearly surprising that the average betas of shipping companies are close to or even below unity. Kavussanos and Visvikis (2006) argue that the shipping industry is one of the most cyclical industrial sectors, which is characterized by high operating leverage and high financial leverage. All three risks are sources of a stock's covariance (beta) risk, and given that these risks are cumulative one should expect shipping betas well above 1.00. However, our results confirm earlier findings by Kavussanos et al (2003) and Drobetz et al (2010), who also report shipping stock betas below unity in factor model specifications.

Finally, the CAPM requires the risk-free rate to determine an appropriate discount rate. We use the average 3-month USD Libor of 4.27 per cent (per year) during our sample period from January 1996 to December 2007. ${ }^{10}$ The average (logarithmic) return of the MSCI world stock market index was 8.24 per cent per year. On the basis of securities market line (SML) analysis and our equallyweighted industry betas, the risk-adjusted discount rates (denoted as $r$ ) are given as $8.24 \%[=4.27 \%+1.00 \times(8.24 \%-4.27 \%)]$ for container, $7.57 \%$ $[=4.27 \%+0.83 \times(8.24 \%-4.27 \%)]$ for tanker and $7.33 \%[=4.27 \%+0.77 \times$ $(8.24 \%-4.27 \%)]$ for bulker vessels.

\section{Performance components of a one-ship company}

In order to construct a performance index for KG funds, the performance components of the one-ship companies contained in the index portfolio must be defined. As shown in Figure 2, during a given period these components consist of the change in the market value of the equity capital plus the payouts to investors. Figure 3 explains in detail how to determine the periodical performance components of a one-ship company. The vessel is acquired and the purchase price $\left(M V_{0}^{\text {Ship }}\right)$ is paid during the investment stage $(t=0)$. All founding and fundraising activities cause some additional expenses $\left(A E_{0}\right)$. The complete investment sum is financed with debt $\left(D C_{0}\right)$ and equity capital $\left(E C_{0}\right)$. After the ship has been operated for one period $(t=1)$, the total assets of the company are the sum of the current market value of the vessel $\left(M V_{1}^{\text {Ship }}\right)$ and the cash flow to equity $\left(C F_{1}^{E C}\right)$. This cash flow (after interest payments) can potentially be distributed to equity investors $\left(P_{1}\right)$ or remain (fully or partly) as a liquidity reserve $\left(L R_{1}\right)$ in the one-ship company. The assets continue to be financed with debt $\left(D C_{1}\right)$ and equity capital. Specifically, the equity capital after distribution $\left(E C_{1}\right)$ remains in the one-ship company and contributes to finance total assets.

Our goal is to construct a performance index for KG funds, and hence both the value of the equity capital and the distributions to equity investors are needed. Specifically, at the end of the first operating period, the value of the 


\begin{tabular}{|c|c|c|}
\hline \multicolumn{3}{|l|}{ Investment phase } \\
\hline Point in time & Investment & Financing \\
\hline $\mathbf{t}=\mathbf{0}$ & $\mathbf{M V}_{0}^{\text {Ship }}+\mathbf{A E}_{0}$ & $\mathrm{EC}_{0}+\mathrm{DC}_{0}$ \\
\hline \multicolumn{3}{|l|}{ Operating phase } \\
\hline Point in time & Assets & Financing \\
\hline$t=1$ & $\begin{array}{l}\mathrm{MV}_{1}^{\text {Ship }}+\mathrm{CF}_{0,1}^{\mathrm{EC}}= \\
\mathrm{MV}_{1}^{\text {Ship }}+\mathrm{LR}_{1}+\mathrm{P}_{1}\end{array}$ & $\mathrm{EC}_{1}+\mathrm{P}_{1}+\mathrm{DC}_{1}$ \\
\hline Performance components: & $\begin{array}{l}\mathrm{EC}_{1}=\mathrm{MV}_{1}^{\text {Ship }}-\mathrm{DC}_{1}+\mathrm{LR}_{1} \\
\mathrm{P}_{1}=\mathrm{CF}_{0,1}{ }^{\mathrm{EC}}-\mathrm{LR}_{1}\end{array}$ & \\
\hline Point in time & Assets & Financing \\
\hline $\mathbf{t}=\mathbf{2}$ & $\begin{array}{l}\mathrm{MV}_{2}^{\text {Ship }}+\mathrm{LR}_{1}+\mathrm{CF}_{1,2}{ }^{\mathrm{EC}}= \\
\mathrm{MV}_{2}^{\text {Ship }}+\mathrm{LR}_{2}+\mathrm{P}_{2}\end{array}$ & $\mathrm{EC}_{2}+\mathrm{P}_{2}+\mathrm{DC}_{2}$ \\
\hline Performance components : & $\begin{array}{l}\mathbf{E C}_{2}=\mathbf{M V}_{\mathbf{2}}^{\text {Ship }}-\mathrm{DC}_{2}+\mathbf{L R}_{2} \\
\mathbf{P}_{\mathbf{2}}=\mathrm{CF}_{\mathbf{1 , 2}}{ }^{\mathrm{EC}}-\left(\mathbf{L R}_{2}-\mathbf{L R}_{\mathbf{1}}\right)\end{array}$ & \\
\hline
\end{tabular}

Figure 3: Periodical performance components of a one-ship company.

equity capital is the market value of the KG vessel minus the debt outstanding plus the liquidity reserve of the one-ship company:

$$
E C_{1}=M V_{1}^{\text {Ship }}-D C_{1}+L R_{1}
$$

At the end of the second period, the value of the equity capital can be calculated identically. Generally, the value of the equity capital at the end of period $t$ can be determined as follows:

$$
E C_{t}=M V_{t}^{\text {Ship }}-D C_{t}+L R_{t}
$$

The initial equity capital invested during the investment stage $\left(E C_{0}\right)$ can be obtained from the investment plan of the KG fund. However, the value of the equity capital at time $t$ is not observable on the market and needs to be determined based on equation (4). Finally, for the last period (the liquidation phase) we have:

$$
E C_{n}=M V_{n}^{\text {Ship }}-D C_{n}+L R_{n}
$$

Eventually, there is a final technical caveat. The value of the equity capital of the one-ship company may be subject to strong fluctuations given the high volatility 
of vessel prices. Strong variations can potentially imply that the market value of the vessel falls below the value of the ship mortgage loan. In this case, the equity capital of the one-ship company becomes negative, and in theory the company becomes insolvent. ${ }^{11}$ However, in practice, the one-ship companies in our sample were never liquidated and remained in the performance records of the issuing houses. Therefore, it is necessary to define a lower limit for the equity capital. We define the lower limit of the value of the equity capital as 27.75 per cent of the KG fund's nominal limited liability capital. While clearly arbitrary, this value represents the average initial 'soft' costs (including any agios) and hence amounts to the founding costs of the company. ${ }^{12}$ If the value of the equity capital of a oneship company drops below 27.75 per cent of the nominal limited liability capital, the value of the equity capital will be set back to this lower limit. Taken together, the methodology presented in this section allows us to compute the monthly time series of equity values and payouts to the limited partners of a KG fund. In the next step, this raw data must be condensed into a performance index.

\section{Specification of the index formula}

An important issue in every index concept is the choice of the weighting scheme. Intuitively, the weighting scheme should be determined by the composition of the underlying portfolio, whose performance the index basket is supposed to mimic. A uniformly-weighted index is the simplest choice; it replicates the performance of a portfolio where equal amounts are invested into each one-ship company at the base date. An equally-weighted index best describes the KG fund portfolio of a private investor. One expects that a private investor's participation in any given KG fund is neither dependent on the size and the type of the vessel nor on its purchasing price. Accordingly, an equally weighted performance index for KG funds (PIA) at reporting date $t$ is calculated as an arithmetic mean of the price measures of all $N$ one-ship companies contained in the index basket:

$$
P I A_{t}=C N_{T} \times \frac{1}{N} \sum_{i=1}^{N} \frac{\left(E C_{i t}+P_{i t}\right) \times C_{i t}^{D}}{E C_{i o} \times C_{i t}^{C A}} \times \text { Basis }
$$

A performance index for KG funds is supposed to capture only the market-induced performance, which results from changes of supply and demand. Therefore, it is necessary to eliminate any external influences: (i) changes of the composition of the index basket (due to a vessel being sold and the one-ship company being liquidated or new funds being issued), (ii) payouts to investors and (iii) different kinds of corporate actions. These influences are incorporated into the index

\footnotetext{
(C) 2013 Macmillan Publishers Ltd. 1479-2931 Maritime Economics \& Logistics $\quad$ Vol. 15, 1, 32-71 45
} 
formula by using an index-specific chaining factor $\left(\mathrm{CN}_{T}\right)$, a payouts correction factor $\left(C_{i t}^{D}\right)$ and a correction factor for various corporate actions $\left(C_{i t}^{C A}\right)$, such as equity capital increases.

The index-specific chaining factor $\left(\mathrm{CN}_{T}\right)$ indicates how often the investor can purchase the new index basket using the proceeds from selling the old index basket; it is calculated as:

$$
C N_{T}=\frac{P I A_{T}^{\text {old }}}{P I A_{T}^{\text {new }}}
$$

$T$ denotes the time of the last chaining. PIA ${ }^{\text {old }}$ represents the index level before chaining, calculated using the composition of the index portfolio before chaining. PIA ${ }^{\text {new }}$ also describes the index level before chaining, but it is calculated using the composition of the index after chaining.

The payouts correction factor $\left(C_{i t}^{D}\right)$ at time $t$ for every one-ship company $i$ contained in the index portfolio reflects the assumption that the payouts $\left(P_{i t}\right)$ are reinvested in the distributing one-ship company; it is calculated as:

$$
C_{i t}^{D}=\frac{E C_{i, t-1}+P_{i, t-1}}{E C_{i, t-1}} \times C_{i, t-1}^{D}
$$

In the past, KG funds were frequently financed with dormant equity upholding an option of conversion into limited liability capital. ${ }^{13}$ If the conversion option is exercised, it represents an increase of share capital comparable to a conditional increase of share capital through an exchange of convertible bonds into ordinary shares in stock corporations (Bleymüller, 1966). Upon conversion of the dormant equity holdings in limited liability capital, the one-ship company is relieved from redemption. Other corporate actions that are sometimes observed in closed-end funds and need to be incorporated into the index computation are increases of the share capital by cash investments (additional contributions) and decreases of the share capital by paying out shareholders. As a result, the equity capital of the oneship company either increases or decreases. The correction factor at time $t$ for these kinds of corporate actions $\left(C_{i t}^{C A}\right)$ in one-ship company $i$ is:

$$
C_{i t}^{A}=\frac{\left(L C_{i, t-1}^{\text {old }}+L C_{i t}^{\text {new }}\right) \times \frac{E C_{i, t-1}}{L C_{i, t-1}^{\text {od }}}}{E C_{i, t-1}+L C_{i t}^{\text {new }}} \times C_{i, t-1}^{C A}
$$

where $L C_{i, t-1}^{o l d}$ is the nominal limited liability capital of one-ship company $i$ at time $t-1$, and $L C_{i, t-1}^{\text {new }}$ is the additional limited liability capital that has been created through some corporate action at time $t$. 
On the basis of the index formula in equation (6), it becomes possible to compute our performance index for KG funds. The index starts on 1 January 1997 with a basis of 100 and is chained on a monthly basis. All KG funds that were already issued before this base date are included into the index using the value of their equity capital at the base date. In this case, the initial costs of the one-ship company (that is, the fund costs from the investment phase) would not be taken into account and hence would not be reflected in the performance of the one-ship company. Accordingly, these older KG funds suffer from a performance disadvantage compared with the younger funds (whose initial costs have been correctly incorporated into the funds' cash flow during the investment phase). In order to correct for this disadvantage, we add a premium to the value of the equity capital with which all funds from before 1 January 1997 are included into the index. This premium amounts to 27.75 per cent of the equity capital; it again represents the average funds costs of a one-ship company (see above).

\section{Index Calculation}

\section{Data basis for the KG performance index}

The market value of the equity capital of a one-ship company is not observable, and hence it must be determined based on our cash flow statement described above. The information required for calculating the KG index can be divided into market- and fund-specific data. Market-specific information relates to ship prices and freight rates, which are necessary for determining the market value of the equity capital of the one-ship company. This information is taken from Clarkson Research Services Ltd.; it is available for container ships from 725 TEU to 5000 TEU, for tankers with a maximum load of $30000 \mathrm{tdw}$ to $310000 \mathrm{tdw}$ and for bulkers with a maximum load of $30000 \mathrm{tdw}$ to $170000 \mathrm{tdw} .{ }^{14}$

Fund-specific information relates to the technical specifications of the fund ships as well as the data from the investment plan and all further data regarding periodical payouts, redemptions and changes of the liquidity reserve. All these information can be found in the performance records issued by the KG equity houses. Unlike market-specific information, which is available on a weekly or monthly basis, the financial statements of the individual KG funds are only published annually. However, data is needed on a monthly basis to construct our index, and therefore we divide the annual data by 12 and assume a linear development over the year. Although clearly ad hoc, this procedure seems nevertheless realistic because charter revenues are paid by the charterer on a monthly basis.

(C) 2013 Macmillan Publishers Ltd. 1479-2931 Maritime Economics \& Logistics Vol. 15, 1, 32-71 47 
On the basis of the KG Finance and Shipping Reports published by Clarkson Research Services Ltd. (2008) and a comprehensive study of the German KG market by Feri EuroRating Services AG (2009), we identify 1614 KG funds. We can partly gather market- and fund-specific information for 927 funds. However, all necessary data to compute the index can only be collected for 323 funds (representing 34.84 per cent of the full sample). Low legal disclosure requirements for KG funds are a major problem, and therefore data collection requires mostly manual efforts and active cooperation of the KG issuing houses. The number of funds contained in the index depends on those KG issuing houses that were willing to provide the necessary historical data. Appendix B shows an overview of the number of KG funds per issuing house.

\section{Calculation of the KG index}

On the basis of the index concept and the historical data described above, we are able to compute the aggregate KG index, labelled PIA. Figure 4 depicts the development of this index over time, starting at a basis of 100 on 1 January 1997. The index first declines, which can be explained by the very high initial fund costs of 27.75 per cent and the poor market environment during this early sample period. Moreover, the mid-1990s experienced a tax-induced newbuilding boom in the container sector, leading to a supply surplus and decreasing freight rates. This trend was further aggravated by the Asian economic crisis and its effects on world trade. After a bottom in Spring 1999, the index rises until the second quarter of 2001. Due to the economic crises after the terrorist attacks on 11 September 2001, the index again declines until mid-2002. It then exhibits a long and steep upward trend, which reaches its peak with 222.69 points in September 2005. One reason for this boom in the shipping industry is attributable to the high economic growth in China. Eventually, the strong fleet growth has led to temporary falling freight rates, implying a slight decrease of the KG index until mid-2006. Since then, the index again shows a stable upward trend and reaches its historical peak with 266.94 points in December 2007. Due to data availability, the index ends just before the global financial crisis - which has had a dramatic impact on shipping markets - has started. $^{15}$

Table 2 shows the number of ships and ship types contained in the index portfolio in each year during the sample period. The KG index starts with 62 container ships in January 1997 and increases to a total of 323 ships in December 2007. Even at the end of the sample period, container ships are the dominant sector with 253 ships, which represents 78 per cent of our sample. Tankers are the second largest sector with 50 ships in 2007 (16 per cent of the total). Finally, there are 20 bulkers in the index basket in 2009 (6 per cent of the 


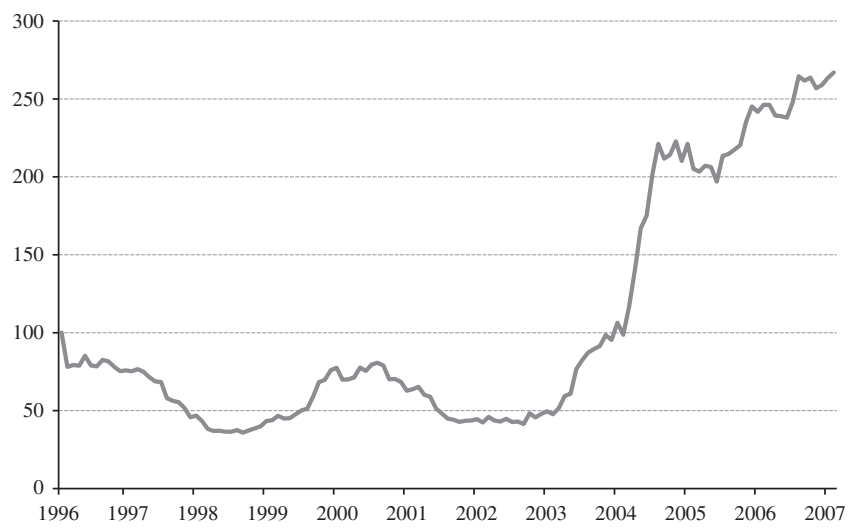

Figure 4: Time evolution of the aggregate KG index (PIA).

total). According to Clarkson Research Services Ltd. (2008) and Feri EuroRating Services AG (2009), these percentages are representative for the total fleet structure that was financed through KG funds in the past.

\section{Statistical Analysis of the KG Performance Index}

This section compares the characteristics of our KG index with a comprehensive set of other shipping-related indices. In addition to the aggregate KG index (PIA) shown in Figure 4, we also analyse three sub-indices for container (PIC), tanker (PIT) and bulker (PIB) vessels (see Table 4). These KG fund indices are compared with a variety of vessel price indices, freight rate indices and a maritime stock index. We start with a brief description of the data basis and proceed with an analysis of the distributional characteristics as well as a correlation analysis. Finally, we present the results of a principal component analysis (PCA), which potentially allows identifying a specific 'KG factor' within the set of shippingrelated index data.

\section{Database for the statistical analysis}

The following analysis is carried out over two sub-periods, the first from 31 December 1996 to 31 December 2007 and the second from 30 September 2002 to 31 December 2007. The later sub-period is examined because most indices have a shorter history than our KG indices. All shipping-related indices are described in Table 3. During our analysis, we take the view of an EUR-investor. Almost all KG funds have the EUR as their currency of denomination, the investors' capital 


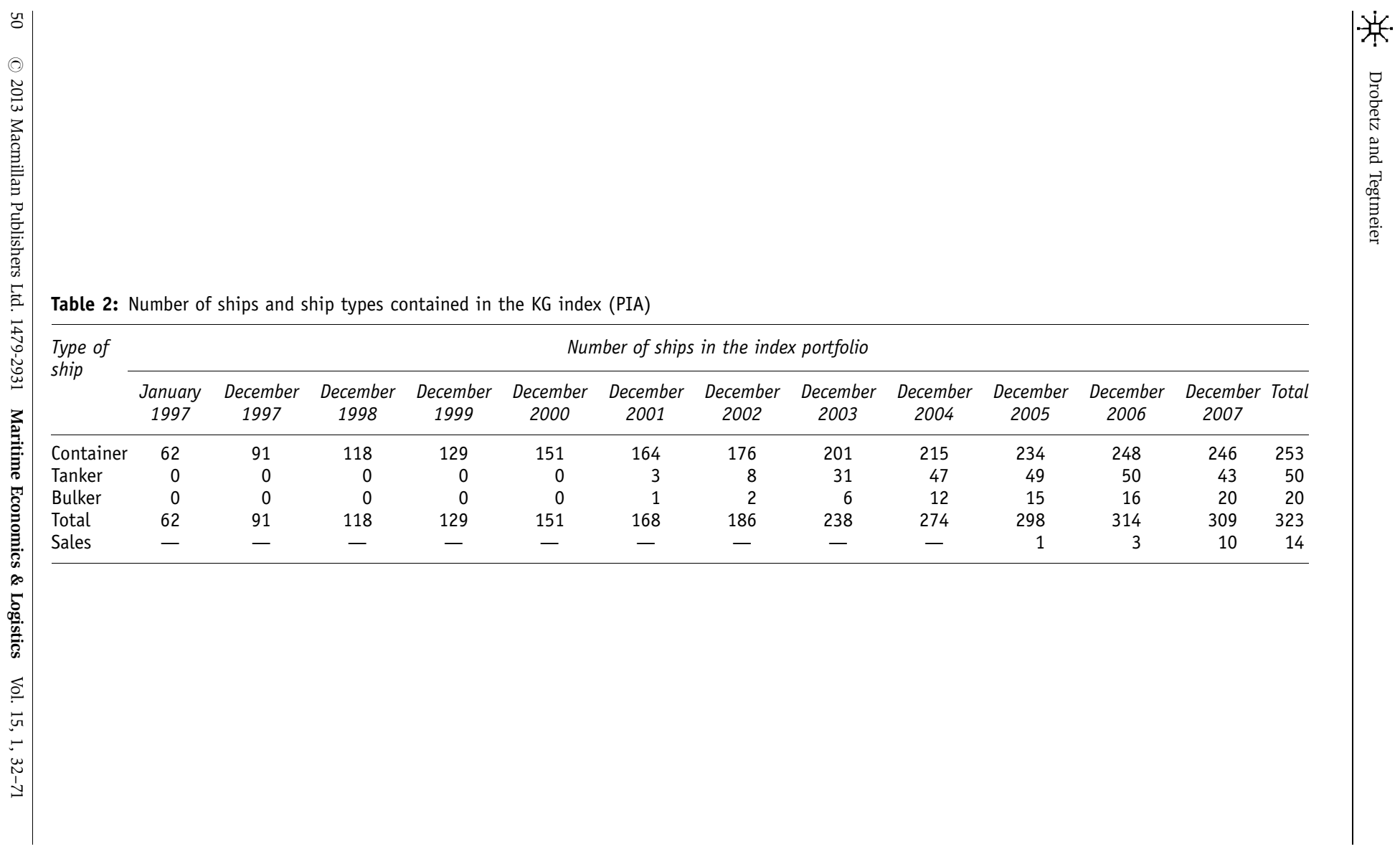


Table 3: Description of shipping-related indices

\begin{tabular}{|c|c|c|c|}
\hline Index & Abbreviation & Description & Source \\
\hline PI Aggregate & PIA & $\begin{array}{l}\text { Performance of a diversified portfolio } \\
\text { of one-ship companies investing in } \\
\text { container, tanker and bulker vessels }\end{array}$ & Own computations \\
\hline PI Container & PIC & $\begin{array}{l}\text { Performance of a diversified portfolio of } \\
\text { one-ship companies investing in } \\
\text { container vessels }\end{array}$ & Own computations \\
\hline PI Tanker & PIT & $\begin{array}{l}\text { Performance of a diversified portfolio of } \\
\text { one-ship companies investing in } \\
\text { tanker vessels }\end{array}$ & Own computations \\
\hline PI Bulker & PIB & $\begin{array}{l}\text { Performance of a diversified portfolio of } \\
\text { one-ship companies investing in } \\
\text { bulker vessels }\end{array}$ & Own computations \\
\hline $\begin{array}{l}\text { Clarkson Newbuildung } \\
\text { Price Index }\end{array}$ & CNBI & $\begin{array}{l}\text { Performance of new building prices of } \\
\text { tankers and bulkers }\end{array}$ & $\begin{array}{l}\text { Clarkson Research } \\
\text { Services Ltd }\end{array}$ \\
\hline $\begin{array}{l}\text { Clarkson Secondhand } \\
\text { Price Index }\end{array}$ & CSHI & $\begin{array}{l}\text { Performance of second hand prices of } \\
5 \text {-year old container ships, tankers and } \\
\text { bulkers }\end{array}$ & $\begin{array}{l}\text { Clarkson Research } \\
\text { Services Ltd }\end{array}$ \\
\hline $\begin{array}{l}\text { Clarkson } \\
\text { Containership } \\
\text { Newbuildung Price } \\
\text { Index }\end{array}$ & CCNBI & $\begin{array}{l}\text { Performance of new building prices of } \\
\text { container ships }\end{array}$ & $\begin{array}{l}\text { Clarkson Research } \\
\text { Services Ltd }\end{array}$ \\
\hline $\begin{array}{l}\text { Clarkson } \\
\text { Containership } \\
\text { Secondhand Price } \\
\text { Index }\end{array}$ & CCSHI & $\begin{array}{l}\text { Performance of second hand prices of } \\
10 \text {-year old container ships }\end{array}$ & $\begin{array}{l}\text { Clarkson Research } \\
\text { Services Ltd }\end{array}$ \\
\hline $\begin{array}{l}\text { Clarkson Tanker } \\
\text { Newbuildung Price } \\
\text { Index }\end{array}$ & CTNBI & $\begin{array}{l}\text { Performance of new building prices of } \\
\text { tankers }\end{array}$ & $\begin{array}{l}\text { Clarkson Research } \\
\text { Services Ltd }\end{array}$ \\
\hline $\begin{array}{l}\text { Clarkson Tanker } \\
\text { Secondhand Price } \\
\text { Index }\end{array}$ & CTSHI & $\begin{array}{l}\text { Performance of second hand prices of } \\
5 \text {-year old tankers }\end{array}$ & $\begin{array}{l}\text { Clarkson Research } \\
\text { Services Ltd }\end{array}$ \\
\hline $\begin{array}{l}\text { Clarkson Bulker } \\
\text { Newbuildung Price } \\
\text { Index }\end{array}$ & CBNBI & $\begin{array}{l}\text { Performance of new building prices of } \\
\text { bulkers }\end{array}$ & $\begin{array}{l}\text { Clarkson Research } \\
\text { Services Ltd }\end{array}$ \\
\hline $\begin{array}{l}\text { Clarkson Bulker } \\
\text { Secondhand Price } \\
\text { Index }\end{array}$ & CBSHI & $\begin{array}{l}\text { Performance of second hand prices of } \\
5 \text {-year old bulkers }\end{array}$ & $\begin{array}{l}\text { Clarkson Research } \\
\text { Services Ltd }\end{array}$ \\
\hline ClarkSea Index & CSI & $\begin{array}{l}\text { Performance of earnings of container } \\
\text { ships, tankers and bulkers }\end{array}$ & $\begin{array}{l}\text { Clarkson Research } \\
\text { Services Ltd }\end{array}$ \\
\hline HARPEX & HARPEX & $\begin{array}{l}\text { Performance of charter rates of container } \\
\text { ships }\end{array}$ & $\begin{array}{l}\text { Harper Petersen \& } \\
\quad \text { Co }\end{array}$ \\
\hline $\begin{array}{l}\text { Baltic Dirty Tanker } \\
\text { Index }\end{array}$ & BDTI & Performance of dirty tanker charter rates & $\begin{array}{l}\text { Clarkson Research } \\
\text { Services Ltd }\end{array}$ \\
\hline $\begin{array}{l}\text { Baltic Clean Tanker } \\
\text { Index }\end{array}$ & $\mathrm{BCTI}$ & Performance of clean tanker charter rates & $\begin{array}{l}\text { Clarkson Research } \\
\text { Services Ltd }\end{array}$ \\
\hline Baltic Dry Index & BDI & Performance of bulker charter rates & $\begin{array}{l}\text { Clarkson Research } \\
\text { Services Ltd }\end{array}$ \\
\hline ShipInx & ShipInx & $\begin{array}{l}\text { Performance of } 30 \text { biggest listed } \\
\text { companies of the maritime industry }\end{array}$ & $\begin{array}{l}\text { Thomson Financial } \\
\text { Datastream }\end{array}$ \\
\hline
\end{tabular}


contributions are made in EUR and investors receive their dividends in EUR. Therefore, we convert our KG index and all other shipping-related indices from USD into EUR. Price series are transformed into monthly continuously compounded returns.

\section{Distributional characteristics}

Tables 4 and 5 show the descriptive statistics of all indices. We start in Table 4 with the longer sample period from 31 December 1996 to 31 December 2007. The ClarkSea Index (CSI) boasts the highest average monthly return with 0.88 per cent. KG funds exhibit average monthly returns of 0.78 per cent (the aggregate index, PIA) and 0.66 per cent (the container sub-index, PIC). The average monthly return of the Clarkson ship price indices range between 0.06 per cent for the CNBI (newbuilding index) and 0.28 per cent for the CSHI (second-hand index; see Table 3 for a description), while the HARPEX (container charter rate index) achieves a monthly average return of only 0.09 per cent. One reason for the comparatively high returns of our KG indices (except the CSI) in comparison with other shipping indices is that they are performance indices, whereas the other shipping indices are simple price indices (without payouts reinvested into the fund). Moreover, KG funds are financed with both debt and equity capital. A part of the higher (equity) returns is presumably attributable to the leverage effect.

The CSI exhibits the highest standard deviation of 8.63 per cent per month. The monthly standard deviation of KG funds ranges between 6.95 per cent (for the PIA) and 7.21 per cent (for the PIC). The HARPEX shows a standard deviation of 6.64 per cent per month. The standard deviations of the ship price indices are substantially lower and range between 2.96 per cent (for the CNBI) and 4.55 per cent (for the CCSHI) per month. Another observation is that excess kurtosis is positive for all indices, except for the CSI. Excess kurtosis indicates a higher likelihood for an extreme event in relation to the normal distribution (fat tails). Specifically, excess kurtosis implies that the distribution has a more acute peak around the mean (hence a lower probability for values near the mean than a normally distributed variable) and fatter tails (hence a higher probability for extreme values than a normally distributed variable). Our KG indices exhibit pronounced fat tails. The empirical distribution of several indices is not symmetric and is instead characterized by positive skewness; this indicates that the tail on the right-hand side is longer than the left-hand side and the bulk of the values lie to the left of the mean. Accordingly, on the basis of the Jarque-Bera (JB) test statistic, the null hypothesis of a normal distribution must be rejected at the 1 per cent significance level for the returns of both KG fund indices (PIA 
Table 4: Descriptive statistics (31 December 1996-31 December 2007)

\begin{tabular}{|c|c|c|c|c|c|c|c|c|c|}
\hline $\begin{array}{l}\text { Index/ } \\
\text { Sector }\end{array}$ & $\begin{array}{c}\text { Mean } \\
(\%)\end{array}$ & $\begin{array}{l}S D \\
(\%)\end{array}$ & $\begin{array}{l}\text { Minimum } \\
(\%)\end{array}$ & $\begin{array}{c}\text { Maximum } \\
(\%)\end{array}$ & Skewness & $\begin{array}{l}\text { Excess } \\
\text { kurtosis }\end{array}$ & $J B$ test & $A C(1)$ & $A C(2)$ \\
\hline \multicolumn{10}{|c|}{ Aggregate (container, tanker, bulker) } \\
\hline PIA & 0.74 & 6.95 & -24.75 & 23.30 & 0.11 & 1.75 & $17.22^{* * *}$ & $0.20 * *$ & $0.31^{* *}$ \\
\hline CNBI & 0.14 & 2.96 & -9.59 & 8.75 & -0.01 & 0.54 & 1.61 & 0.15 & 0.05 \\
\hline CSHI & 0.28 & 3.30 & -10.30 & 8.64 & -0.25 & 0.31 & 1.91 & $0.21^{* *}$ & 0.08 \\
\hline CSI & 0.88 & 8.63 & -17.90 & 25.76 & 0.25 & -0.11 & 1.42 & $0.39 * *$ & 0.09 \\
\hline \multicolumn{10}{|c|}{ Container } \\
\hline PIC & 0.66 & 7.21 & -24.75 & 25.55 & 0.27 & 2.05 & $24.66^{* * *}$ & $0.17^{* *}$ & 0.29 ** \\
\hline CCNBI & 0.06 & 3.39 & -7.81 & 9.82 & 0.32 & 0.63 & 4.39 & 0.10 & 0.08 \\
\hline CCSHI & 0.23 & 4.55 & -15.96 & 18.25 & 0.40 & 2.93 & $50.72^{* * *}$ & 0.15 & $0.25^{\text {** }}$ \\
\hline HARPEX & 0.09 & 6.64 & -22.04 & 15.21 & -0.39 & 0.50 & $4.77^{*}$ & $0.34^{* *}$ & 0.12 \\
\hline
\end{tabular}

All numbers are based on monthly continuously compounded returns. All abbreviations are explained in Table $3 .{ }^{*},{ }^{* *},{ }^{* *}$ denote a 10 per cent, 5 per cent and 1 per cent level of significance.

and PIC). The normality assumption must also be rejected for the CCSHI and the HARPEX.

The autocorrelations of all indices are positive at lag 1 (AC1) and lag 2 (AC2), and many of them are even statistically significant (including our KG performance indices). Positive autocorrelations of shipping-related indices should not come as a surprise. For example, Bessler et al (2008) argue that changes in freight rates should be serially correlated because they are determined by the interaction of demand and supply for freight services, hence at a specific point in time for a certain time period and route. However, the opportunities for substitution over time as well as substitution across routes and vessel types are very limited, implying autocorrelation in spot freight rates. Because storability and any form of substitution over time and between routes and vessels are limited, the time series patterns in spot freight rates cannot be exploited profitably by trading strategies. With persistence in the demand for freight services and inelastic supply, changes in the spot freight rates can exhibit autocorrelation even if shipping markets are fully informationally efficient (Bessler et al, 2008).

According to Getmansky et al (2004), there may also be other reasons for the observed autocorrelation structures. One obvious explanation is the lack of liquidity and related valuation problems. Most important, the Clarkson secondhand ship price indices incorporate actual transaction prices. Provided that no sales have taken place, broker valuations are consulted. These valuations are based on the last market rates (or, if necessary, even further back) plus a manual adjustment. This procedure potentially leads to smoothed index returns with high autocorrelation and low volatility. The effect tends to be even further

(C) 2013 Macmillan Publishers Ltd. 1479-2931 Maritime Economics \& Logistics $\quad$ Vol. 15, 1, 32-71 53 
strengthened in the context of our KG indices through the assumption of a minimum value for the nominal limited liability capital, which is a technical requirement in our index concept. Moreover, the annual fund-specific data is divided by 12 , implying that a linear development is assumed and the resulting index return series is smoothed. From a statistical point of view, the existence of autocorrelation may lead to biased risk measures. Specifically, autocorrelation causes an underestimation of volatility and an overestimation of Sharpe ratios (Brooks and Kat, 2002; Lo, 2002).

Table 5 presents descriptive statistics for the larger set of indices that are available during the shorter sample period from 30 September 2002 to 31 December 2007. ${ }^{16}$ The mean returns are higher compared with the longer sample period in Table 4. KG funds investing in bulker vessels (PIB) boast the highest average return with 3.21 per cent per month. The ShipInx, which includes a portfolio of publicly listed firms from the maritime industry, exhibits a slightly lower monthly average return of 2.72 per cent. The monthly average returns of the other KG indices range between 1.11 per cent (the PIT) and 2.36 per cent (the PIA). The monthly average returns of the freight rate indices are substantially lower (except the CSI and the BDI), and the same also applies for the vessel price indices (except the CBSHI as a proxy for the second-hand prices of bulkers with a monthly average return of 1.89 per cent). Again, reasons for the higher returns of KG funds and the ShipInx are that both indices represent performance indices and that the companies contained in both index baskets are financed with debt and equity capital, and thus the leverage effect is at work.

Accompanying the higher mean returns, the volatility also increases for most indices during the later sample period. As one would expect, comparing the standard deviations of our KG fund indices and the ShipInx with the freight rate indices, freight rates exhibit a higher volatility (except the HARPEX). The skewness measures of our KG indices do not allow a consistent interpretation. The skewness of the aggregate KG index (PIA) and the KG container sub-index (PIC) changes from positive to negative. The same change is observable for the ShipInx. In contrast, both the KG tanker (PIT) and the KG bulker (PIB) subindices exhibit positive skewness. Following the increase in volatility, excess kurtosis is also higher for most indices. Most important, the value of the excess kurtosis for our aggregate KG index (PIA) more than doubles from 1.75 to 4.66. Accordingly, the JB test statistic rejects the null hypothesis of normally distributed returns for all our KG indices. In contrast, for the ShipInx and for most freight rate indices, the null hypothesis of normality cannot be rejected. A final observation is that the autocorrelations - although positive for most indices - are lower during the later sub-period (e.g., due to higher liquidity in the more recent years). 
Table 5: Descriptive statistics (30 September 2002-31 December 2007)

\begin{tabular}{|c|c|c|c|c|c|c|c|c|c|}
\hline Index/Sector & Mean (\%) & $S D(\%)$ & Minimum (\%) & Maximum (\%) & Skewness & Excess kurtosis & $J B$ test & $A C(1)$ & $A C(2)$ \\
\hline \multicolumn{10}{|c|}{ Aggregate (container, tanker, bulker) } \\
\hline PIA & 2.36 & 8.00 & -32.22 & 23.30 & -0.64 & 4.66 & $61.30 * * *$ & 0.04 & $0.29 * *$ \\
\hline CNBI & 0.27 & 2.78 & -5.00 & 8.75 & 0.54 & 0.57 & 3.92 & 0.03 & 0.02 \\
\hline CSHI & 0.66 & 3.21 & -5.89 & 8.64 & 0.07 & -0.30 & 0.29 & 0.10 & 0.03 \\
\hline CSI & 1.91 & 10.25 & -17.90 & 25.76 & 0.18 & -0.81 & 2.09 & $0.40^{* *}$ & -0.02 \\
\hline ShipInx & 2.72 & 5.53 & -14.11 & 17.62 & -0.17 & 0.75 & 1.80 & -0.12 & 0.16 \\
\hline \multicolumn{10}{|l|}{ Container } \\
\hline PIC & 2.17 & 8.49 & -32.29 & 25.55 & -0.35 & 3.93 & $41.88^{* * *}$ & 0.01 & $0.26^{* *}$ \\
\hline CCNBI & 0.26 & 3.33 & -5.34 & 9.82 & 0.95 & 1.22 & $13.46^{* * *}$ & 0.06 & 0.12 \\
\hline CCSHI & 0.69 & 5.07 & -15.96 & 18.25 & 0.33 & 3.25 & $28.79^{* * *}$ & 0.10 & $0.26^{* *}$ \\
\hline HARPEX & 0.39 & 6.26 & -22.04 & 11.94 & -0.59 & 1.42 & 9.00 ** & $0.36^{* *}$ & 0.17 \\
\hline \multicolumn{10}{|l|}{ Tanker } \\
\hline PIT & 1.11 & 9.70 & -30.74 & 39.01 & 0.20 & 4.18 & $46.32^{* * *}$ & $0.38^{* *}$ & 0.16 \\
\hline CTNBI & 0.57 & 2.78 & -5.25 & 9.20 & 0.55 & 0.79 & $4.41^{*}$ & -0.07 & 0.03 \\
\hline CTSHI & 0.95 & 3.25 & -5.89 & 9.98 & 0.50 & 0.95 & $5.00^{*}$ & 0.13 & -0.01 \\
\hline BDTI & 1.13 & 21.72 & -41.35 & 46.18 & 0.17 & -0.56 & 1.12 & $0.72^{\text {** }}$ & $0.39^{* *}$ \\
\hline BCTI & 0.11 & 18.31 & -33.24 & 48.43 & 0.30 & -0.06 & 0.94 & $0.65^{* *}$ & $0.33^{* *}$ \\
\hline \multicolumn{10}{|l|}{ Bulker } \\
\hline PIB & 3.21 & 20.32 & -44.66 & 74.91 & 1.03 & 3.10 & $36.35^{* * *}$ & -0.03 & 0.05 \\
\hline CBNBI & 0.83 & 3.39 & -6.20 & 9.31 & 0.15 & -0.13 & 0.29 & -0.00 & -0.03 \\
\hline CBSHI & 1.89 & 5.92 & -15.36 & 19.49 & 0.06 & 1.34 & $4.75^{*}$ & 0.21 & -0.08 \\
\hline BDI & 2.39 & 14.64 & -33.79 & 42.17 & 0.06 & 0.36 & 0.38 & 0.15 & -0.13 \\
\hline
\end{tabular}

All numbers are based on monthly continuously compounded returns. All abbreviations are explained in Table $3 .{ }^{*},{ }^{* *},{ }^{* *}$ denote a 10 per cent, 5 per cent and 1 per cent level of significance. 


\section{Correlation analysis}

Table 6 shows the correlation matrix of all indices that are available during the full sample period from 31 December 1996 to 31 December 2007. As expected, the correlations are high between the KG indices and the ship price indices. For example, the correlation between the aggregate KG index (PIA) and the CNBI (newbuilding index) as well as the CSHI (second-hand index) are both 0.53 , while the correlation between the aggregate PIA and the CSI is only 0.04. Similar results are observable for our KG container sub-index (PIC). The correlations between the PIC and the CNBI as well as the CSHI are 0.58 and 0.71, respectively. In contrast, the correlation between the PIC and the HARPEX (container charter rate index) is only 0.30 . These findings suggest that the performance of KG funds depends more strongly on the development of ship prices than on the development of freight rates.

A very high correlation of 0.98 between the aggregate KG index (PIA) and the container sub-index (PIC) is not surprising. In fact, until 30 April 2001, the PIA consists only of container funds. Even later during the sample period, containers are the dominating sector within the PIA (with 253 out of 323 ships; see Table 3). Finally, analysing the correlations between ship prices and freight rates, a strong relationship can be observed in the container sector. The correlation between the CCNBI and the HARPEX is 0.52, and the correlation between the CCSHI and the HARPEX is almost identical with 0.51. These high correlations between ship prices and freight rates in the container sector contrast with the other shipping sectors. Looking at the aggregate indices, the correlation between the CNBI and the CSI as well as the CSHI and the CSI is only 0.20 and 0.19 , respectively.

Table 7 shows the correlation matrix for the shorter sample period from 30 September 2002 to 31 December 2007. The correlations between our KG indices

Table 6: Correlation matrix (31 December 1996-31 December 2007)

\begin{tabular}{lcccccccc}
\hline & PIG & CNBI & CSHI & CSI & PIC & CCNBI & CCSHI & HARPEX \\
\hline PIA & 1.00 & 0.53 & 0.53 & 0.04 & 0.98 & 0.60 & 0.67 & 0.31 \\
CNBI & & 1.00 & 0.86 & 0.20 & 0.51 & 0.88 & 0.60 & 0.43 \\
CSHI & & & 1.00 & 0.19 & 0.52 & 0.76 & 0.69 & 0.44 \\
CSI & & & & 1.00 & 0.11 & 0.15 & 0.21 & 0.12 \\
PIC & & & & & 1.00 & 0.58 & 0.71 & 0.30 \\
CCNBI & & & & & & 1.00 & 0.59 & 0.52 \\
CCSHI & & & & & & & 1.00 & 0.51 \\
HARPEX & & & & & & & & 1.00 \\
\hline
\end{tabular}

The correlation coefficients are based on monthly continuously compounded returns. All abbreviations are explained in Table 3.

56 (C) 2013 Macmillan Publishers Ltd. 1479-2931 Maritime Economics \& Logistics Vol. 15, 1, 32-71 
and the ship price indices are again positive, but their levels strongly diverge; they range between 0.02 (PIB and CBSHI) and 0.73 (PIC and CCSHI). It is also notable that the returns of our KG indices are more correlated with the second-hand ship price indices than with the newbuilding price indices (except the bulker sector). The low correlation between the PIB and the CBSHI can be explained by the time variation of the present value of the timecharter contract (given that vessel prices and freight rates are highly correlated), which leads to a smoothing of the value of the fund's equity capital. The correlations between our KG indices and the freight rate indices (except the HARPEX) even tend to be negative. Therefore, we again conclude that the performance of KG funds is more dependent on the variation of vessel prices than on freight rates.

By construction, the correlations between our four KG indices are positive and fall between 0.27 and 0.97. Moreover, the correlations between the KG indices and the ShipInx are low, ranging between -0.08 (ShipInx and PIB) and 0.19 (ShipInx and PIA/PIC). The correlations between the ShipInx and the other indices are equally low; they are between -0.09 (ShipInx and BDTI) and 0.35 (ShipInx and CTSHI). The correlations between freight rate indices and ship price indices are generally not as high as one expects, and in several instances they are even slightly negative. Strong positive correlations are observable in the container sector (HARPEX and CCNBI/CCSHI) and the bulker sector (BDI and CBNBI/CBSHI).

There is a stronger relationship between second-hand vessel price indices and freight rate indices than between newbuilding price indices and freight rate indices. This observation can be explained by the fact that newbuilding prices are mainly determined by the shipyards. They are dependent on the number of available building lots and the capacity of the shipyards. An additional aspect is that ships must first be built, and thus they are only available in the market after a lag of 2 or 3 years depending on construction time. In contrast, the prices for second-hand vessels are more directly related to the development of freight rates. Second-hand vessels are immediately available in the market, and hence their prices are determined by the obtainable revenues in the spot market (Haralambides et al, 2005)

Finally, the correlations between the newbuilding prices and the secondhand prices range between 0.53 (CCNBI and CCSHI) and 0.78 (CNBI and CSHI). These high correlations are consistent with the notion that newbuilding and second-hand ships are close although not perfect substitutes. The market for second-hand ships should be considered as a spot market because vessels are immediately available. In contrast, the market for newly built vessels is a forward market because newbuildings are only available with a delay of 2 or 3 years depending on the construction time.

(C) 2013 Macmillan Publishers Ltd. 1479-2931 Maritime Economics \& Logistics Vol. 15, 1, 32-71 5 


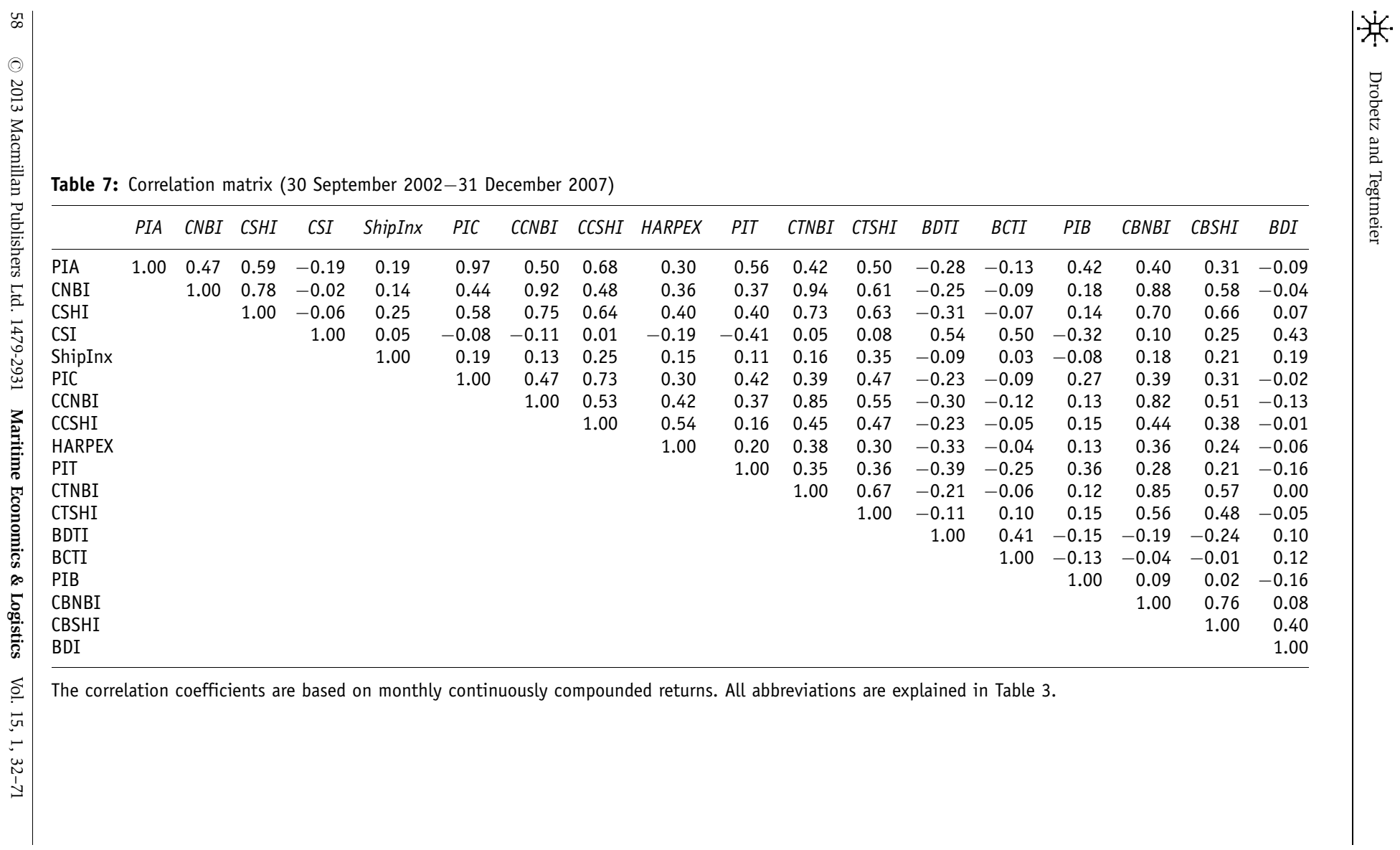




\section{Principal component analysis}

The correlation analysis reveals linear dependencies between our comprehensive set of shipping indices. In this sub-section, our goal is to identify the common structure among our KG indices and other shipping-related indices by sorting these indices into a smaller number of groups depending on their correlations. The resulting classification scheme determines which indices jointly incorporate the same type of information and hence are influenced by the same underlying (although latent unobservable) factors.

Factor analysis is a popular statistical method that identifies structural dependencies between a set of variables and extracts a small number of factors based on the variables' correlation matrix. This technique is based on the notion that a high correlation is an indication for the influence of latent variables, which cannot be directly observed or measured. The extracted factors are not exogenous; they are endogenously determined (based on some linear combinations of the original set of variables) and represent mere statistical factors. Accordingly, their economic meaning can only be interpreted in a given context.

The technique that is most frequently chosen within the broader scope of factor analysis is principal component analysis (PCA), which uses an orthogonal transformation to convert a set of observations of possibly correlated variables into a set of values of uncorrelated variables called principal components (Jolliffe, 2010). By construction, the number of principal components $k$ is less than or equal to the number of original variables $n$ (hence $k<n$ ). PCA extracts the first principal component to have as high a variance as possible (that is, accounts for as much of the variability in the data as possible), and each succeeding component exhibits the highest variance possible under the constraint that it is orthogonal to (uncorrelated with) the preceding components. The idea of PCA to reduce a larger set of drivers (of a set of observations/ variables) to a small number of linearly independent (but purely statistical) factors can be described as:

$$
x_{i}=a_{i 1} F_{1}+a_{i 2} F_{2}+\cdots+a_{i k} F_{k}+d_{i} U_{i}
$$

where $x_{i}$ is the observation of variable $i$; $F_{j}$ the common factor $j ; k$ the number of common factors; $a_{i j}$ the coefficient or factor loading (the correlation between $x_{i}$ and $F_{j}$ ); $U_{i}$ the variable-specific factor (each variable $i$ possesses its specific factor); and $d_{i}$ the loading of the variable-specific factor (the correlation between $x_{i}$ and $U_{i}$ ). More specifically, PCA results in a system of equations for the $n$ variables to be explained, labelled $x_{i}$, and hence

(C) 2013 Macmillan Publishers Ltd. 1479-2931 Maritime Economics \& Logistics Vol. 15, 1, 32-71 59 
equation (10) can be written as:

$$
\begin{gathered}
x_{1}=a_{11} F_{1}+a_{12} F_{2}+\cdots+a_{1 k} F_{k}+d_{1} U_{1} \\
x_{2}=a_{21} F_{1}+a_{22} F_{2}+\cdots+a_{2 k} F_{k}+d_{2} U_{2} \\
\cdots \\
x_{n}=a_{n 1} F_{1}+a_{n 2} F_{2}+\cdots+a_{n k} F_{k}+d_{n} U_{n}
\end{gathered}
$$

or

$$
\left[\begin{array}{c}
x_{1} \\
x_{2} \\
\ldots \\
x_{n}
\end{array}\right]=\left[\begin{array}{cccc}
a_{11} & a_{12} & \ldots & a_{1 k} \\
a_{21} & a_{22} & \ldots & a_{2 k} \\
\ldots & \ldots & \ldots & \ldots \\
a_{n 1} & a_{n 2} & \ldots & a_{n k}
\end{array}\right]\left[\begin{array}{c}
F_{1} \\
F_{2} \\
\ldots \\
F_{k}
\end{array}\right]+\left[\begin{array}{cccc}
d_{1} & 0 & \ldots & 0 \\
0 & d_{2} & \ldots & 0 \\
\ldots & \ldots & \ldots & \ldots \\
0 & 0 & \ldots & d_{n}
\end{array}\right]\left[\begin{array}{c}
U_{1} \\
U_{2} \\
\ldots \\
U_{n}
\end{array}\right]
$$

PCA is based on the assumptions that (i) the specific factors $U_{i}$ are uncorrelated with each other, (ii) the specific factors $U_{i}$ are uncorrelated with the common factors $F_{j}$ and (iii) the common factors $F_{j}$ are uncorrelated with each other. The main result of each PCA is the factor-loading matrix, that is, the matrix with entries $a_{i j}$ in equation (12). This matrix provides information about how well each variable $x_{i}$ can be explained by a common factor $F_{j}$, how well each variable $x_{i}$ can be explained by all common factors $F_{j}$ and how well all variables taken together can be explained by all common factors.

Our PCA is carried out for the later sub-period from 30 September 2002 to 31 December 2007 because all indices - the KG indices and all other shippingrelated indices shown in Table 4 above - are available during this time period. All PCA results are shown in Table 8. We use PCA as a method for reducing the number of variables, and thus PCA extracts consecutive factors that account for less and less variability. The decision of when to stop extracting factors depends on when there is only very little 'random' variability left. The nature of this decision is arbitrary, but there are some guidelines. Specifically, we report the variance of the new factors that are successively extracted in the second column in panel A of Table 8 (labelled Total). In the third column, these values are expressed as a percentage of total variance. The variances extracted by the individual factors are called eigenvalues. By construction, the sum of the eigenvalues is equal to the number of variables. Given that we examine a set of 18 shipping-related indices, it requires 18 factors to explain 100 per cent of the total variance. However, Factor 1 already accounts for almost 40 per cent of the variance, Factor 2 for 14.5 per cent and the explanatory power of the consecutive factors drops rapidly. The third column shows the cumulative variance extracted. 
Table 8: Principal component analysis

\begin{tabular}{|c|c|c|c|c|c|}
\hline \multicolumn{6}{|c|}{ Initial eigenvalues } \\
\hline \multicolumn{2}{|l|}{ Component } & Total & \multicolumn{2}{|l|}{$\%$ of Variance } & Cumulative (\%) \\
\hline \multicolumn{6}{|c|}{ Panel A: Explanatory power of extracted statistical factor } \\
\hline 1 & & 7.154 & 39.744 & & 39.744 \\
\hline 2 & & 2.616 & 14.536 & & 54.280 \\
\hline 3 & & 1.541 & 8.560 & & 62.840 \\
\hline 4 & & 1.257 & 6.981 & & 69.821 \\
\hline 5 & & 1.051 & 5.841 & & 75.661 \\
\hline 6 & & 0.920 & 5.112 & & 80.774 \\
\hline 7 & & 0.772 & 4.291 & & 85.064 \\
\hline 8 & & 0.604 & 3.357 & & 88.421 \\
\hline 9 & & 0.466 & 2.586 & & 91.008 \\
\hline 10 & & 0.405 & 2.250 & & 93.257 \\
\hline 11 & & 0.332 & 1.842 & & 95.100 \\
\hline 12 & & 0.303 & 1.681 & & 96.781 \\
\hline 13 & & 0.230 & 1.277 & & 98.058 \\
\hline 14 & & 0.152 & 0.842 & & 98.900 \\
\hline 15 & & 0.105 & 0.582 & & 99.482 \\
\hline 16 & & 0.059 & 0.330 & & 99.812 \\
\hline 17 & & 0.032 & 0.175 & & 99.987 \\
\hline 18 & & 0.002 & 0.013 & & 100.000 \\
\hline \multicolumn{6}{|c|}{ Component } \\
\hline Variable & 1 & 2 & 3 & 4 & 5 \\
\hline \multicolumn{6}{|c|}{ Panel B: Factor loading matrix } \\
\hline CNBI & 0.946 & 0.163 & -0.078 & 0.114 & -0.400 \\
\hline CTNBI & 0.930 & 0.117 & -0.032 & 0.125 & -0.012 \\
\hline CBNBI & 0.922 & 0.072 & -0.026 & 0.107 & 0.141 \\
\hline CCNBI & 0.881 & 0.145 & -0.139 & 0.218 & -0.131 \\
\hline CSHI & 0.742 & 0.292 & -0.105 & 0.340 & 0.164 \\
\hline CBSHI & 0.686 & 0.067 & -0.041 & 0.075 & 0.561 \\
\hline CTSHI & 0.621 & 0.320 & 0.142 & 0.294 & 0.058 \\
\hline PIA & 0.294 & 0.823 & -0.077 & 0.415 & 0.035 \\
\hline PIC & 0.263 & 0.738 & 0.012 & 0.503 & 0.089 \\
\hline PIB & 0.057 & 0.682 & -0.167 & -0.165 & -0.183 \\
\hline PIT & 0.290 & 0.596 & -0.438 & -0.042 & -0.017 \\
\hline BDTI & -0.170 & -0.069 & 0.788 & -0.247 & -0.056 \\
\hline CSI & 0.106 & -0.199 & 0.778 & -0.058 & 0.395 \\
\hline BCTI & -0.013 & -0.074 & 0.771 & 0.074 & -0.023 \\
\hline CCSHI & 0.362 & 0.343 & 0.046 & 0.741 & 0.031 \\
\hline HARPEX & 0.319 & -0.064 & -0.206 & 0.685 & -0.167 \\
\hline ShipInx & 0.057 & 0.010 & -0.048 & 0.491 & 0.447 \\
\hline BDI & 0.003 & -0.098 & 0.135 & -0.062 & 0.869 \\
\hline
\end{tabular}

All abbreviations are explained in Table 3. 
Given how much variance each successive factor extracts, it must be determined how many factors to retain. The Kaiser criterion suggests retaining only factors with eigenvalues greater than 1 . The intuition is that a factor should be dropped unless it extracts a proportion of variance that is larger than the variance contribution of a single variable. According to the Kaiser criterion, we retain five factors (principal components) and ignore all other factors. These five factors account for more than 75 per cent of the total variance of the index returns. A scree plot (not shown here) depicts the eigenvalues in a simple line plot. The place where the smooth decrease of eigenvalues appears to level off to the right of the plot suggests the number of factors under this criterion. In our case, it suggests that only three factors should be kept.

The rotated component matrix or factor-loading matrix is shown in panel B of Table $8 .^{17}$ The entries exhibit the factor loadings, which measure the correlations of the individual variables (the shipping indices) with the five extracted factors. For easier interpretation, the factor loadings are sorted according to size. Although PCA extracts purely statistical factors, our findings have important economic interpretations. The set of ship price indices (CNBI, CTNBI, CBNBI, CCNBI, CSHI, CBSHI and CTSHI) boasts the highest correlation with the first extracted factor. To a large extent, Factor 1 explains the variation of vessel prices, whereas the remaining factors contribute little explanatory power. Therefore, we suggest that Factor 1 is a 'ship price factor'. The only exception is Factor 5, which has a loading of 0.561 on the second-hand prices of bulkers (CBSHI).

Factor 2 provides explanatory power for the variation of our KG indices, as indicated by the loadings on the aggregate KG index (PIA) and the three sub-indices (PIC, PIB and PIT); they range between 0.596 and 0.823 . As expected, the KG indices are influenced by one common factor, and no other index seems to be affected by this factor. Accordingly, we interpret Factor 2 as a 'KG factor', implying that only the KG indices load strongly on this factor. Our KG index does not stand in direct relationship with all other shipping-related indices, and hence it is not simply a linear combination of ship prices and freight rates. We conclude that the KG index incorporates specific information that is primarily of importance for KG funds.

Factor 3 seems to be a 'freight rate factor', which explains a particularly large proportion of the freight rate variation in tanker shipping. The loading of the CSI (incorporating the freight rates in the container, tanker and bulker sector) is 0.778 . The loadings of the two tanker charter rate indices BDTI and BCTI are 0.788 and 0.771 , respectively. In contrast to this interpretation as a freight rate factor, however, both the HARPEX and the BDI exhibit unexpectedly low factor loadings.

Factor 4 explains the variance of freight rates and second-hand ship prices in the container sector. Specifically, it exhibits high factor loadings on the HARPEX and the CCSHI, and therefore this factor is primarily a 'container 
factor'. Finally, Factor 5 explains variations in the BDI, which captures freight rates in the bulker sector, and hence this factor is primarily a 'bulker factor'. We also observe that the ShipInx, an index of listed shipping firms, is affected by both Factor 4 and Factor 5. Accordingly, we cannot identify a unique 'stock market factor' in our set of indices.

Overall, we conclude from our PCA that the variances of our comprehensive set of shipping-related indices are best described by five independent factors. These five statistical factors can be interpreted as a 'ship price factor', a 'KG fund factor', a 'freight rate factor' (particularly for the freight rates within the tanker shipping industry), a 'container factor' and a 'bulker factor'. Most important, our KG indices are not a mere linear combination of ship prices and freight rates, and thus they do not stand in direct relationship with all other shipping-related indices. The aggregate KG index and the three sub-indices for the container, tanker and bulker sectors incorporate specific information, which is primarily of importance for KG funds. From a portfolio theory perspective, our findings support the notion that KG funds offer a distinct return-risk spectrum and additional diversification potential to investors when added to an already diversified portfolio in the maritime industry.

\section{Conclusions}

Despite their economic importance, academic research has granted KG funds only marginal attention. A major reason is the lack of reliable data, which prevents that KG funds are being analysed appropriately within the framework of modern portfolio theory. As KG funds represent an entrepreneurial investment, they are a non-tradable asset class, and hence there are no observable market prices. The performance of an investment in a KG fund is only known ex post when the vessel is sold after 15-20 years of operation and the fund is liquidated. In order to measure the performance of a KG fund on a regular basis during its lifetime, we construct a performance index using fund data over the sample period from December 1996 to December 2007. Our approach to assess the fundamental value of an equity interest in a closed-end ship fund is transparent and strictly oriented along a fund's cash flow statement. The fundamental value of a fund's equity at the end of each month is the sum of the market value of the fund's vessel (based on comparable transaction multiples), its liquidity reserves and the payouts to equity investors. Computing the vessel's market value requires an adjustment for the remaining length of the timecharter contract by discounting 'excess freight rates' using an appropriate hurdle rate. On the basis of this notion, we develop the construction principles of a performance index for KG funds which adheres to the general construction 
rules for stock indices, for example, by using adjustment factors for constituent changes, distributions and capital changes.

Using a hand-collected database for more than 300 German KG funds, we construct an aggregate KG index and three sub-indices for container, tanker and bulker vessels. We analyse their statistical properties in comparison with a comprehensive set of shipping-related indices, such as freight rates indices, newbuilding as well as second-hand price indices, and stock prices of listed firms from the maritime industry. In a first step, we measure the distributional characteristics of these indices and look at their correlation structures in order to examine the co-movement of our KG indices with the other shipping-related indices. The results indicate that the time series development of our aggregate KG index is more strongly dependent on ship prices than on charter rates. In the second step, we use PCA in order to examine whether there are common structures and linkages between the different indices. Looking at the factor loadings, the indices exhibit substantial differences with respect to their return-risk characteristics. Most important, PCA identifies a factor that is specific to KG funds; only the KG indices load strongly on this particular (statistical) factor.

Overall, we conclude that our KG indices are not simply linear combinations of ship prices and freight rates, and they do not stand in direct relationship with all other shipping-related indices. Our indices incorporate information that is specific for KG funds. These properties make the index a valuable tool for shipowners and shipping banks in order to make their investment and financing decisions. From a portfolio theory perspective, they indicate that KG funds are attractive for both private and institutional investors due to their potential diversification benefits.

\section{Notes}

1 The Norwegian KS structures (kommandittselskap) represent a very similar and equally successful financing instrument. Stopford (2009) provides a detailed review of the different instruments of ship financing.

2 Opportunities for investors also exist in debt capital or alternative asset classes in the maritime industry. Examples include corporate shipping (high yield) bonds (Grammenos et al, 2008; Kavussanos and Tsouknidis, 2010), ship mortgage bonds issued by banks as well as freight rate derivatives and hedge funds (Kavussanos and Visvikis, 2006; Alizadeh and Nomikos, 2009). Bessler et al (2010) provide an overview of investment opportunities in the shipping industry.

3 The market capitalization of all international publicly listed shipping companies has declined from about $\$ 300$ billion at the end of 2007 to $\$ 121$ billion at end of 2008 , and hence their share of total world stock market capitalization has decreased from 0.49 per cent to 0.37 per cent (Maritime Services, 2009).

4 In contrast, price indices measure price changes of an index portfolio adjusted by subscription rights and capital changes (but without dividend reinvestments). 
5 If necessary, additional adjustments can be made with respect to technical specifications of a vessel.

6 The current freight rate is approximated by the 6-12-month time charter rate for container vessels and the 1-year time charter rate for tanker and bulker vessels. This choice ensures that the current freight rate is comparable with the fixed time-charter contract.

7 Glen and Martin (2005) provide a survey of time series models for freight.

8 Detailed sensitivity analyses are available from the authors upon request.

9 A noteworthy finding is that the explanatory power of market model regressions is rather low, with $R^{2}$ often below 10 per cent.

10 The risk-free rate must be denominated in the same currency as the firms' cash flows (Bessler et al, 2007). Given that the leading currency in the shipping industry is the USD and we convert all prices into USD, we also use the 3-month USD Libor as the risk-free rate.

11 Benmelech and Bergman (2011) empirically analyse asset price risks and the accompanying 'collateral channel' for the airline industry.

12 This value is taken from the database of the TKL.Fonds Gesellschaft für Fondsconception und -analyse $\mathrm{mbH}$, which contains 341 closed-end ship funds. TKL.Fonds Gesellschaft für Fondsconception und -analyse $\mathrm{mbH}$ is an independent rating agency for closed funds (www.tkl-fonds.de).

13 The main reason for using dormant equity holdings with an option of conversion has been to increase losses for tax purposes during the investment phase.

14 A comprehensive summary of all market-specific information, which are required in our framework, can be found in the official guide of the SFI.TKL Ship Fund Index on the Websites of BÖAG Börsen AG (www.boersen-ag.de) and Fondsbörse Deutschland Beteiligungsmakler AG (www.zweitmarkt.de). Different from the index concept introduced in this study, which is based on actual KG funds, the SFI.TKL Ship Fund Index is based on hypothetical one-ship companies.

15 Recently, most KG funds did not release financial statements due to ongoing recapitalizations. The index can be updated and firms in recapitalization included into the index using the correction factor for corporate actions described in equation (9) once the data is available.

16 As described in the text, taking 30 September 2002 as the new base date requires adding a 27.75 per cent premium to the equity capital of a KG fund in order to account for the initial costs of the one-ship companies. Otherwise, the KG indices would benefit from a performance advantage over all other shipping-related indices.

17 The Varimax method is used in the analytical rotation process. This method is an iterative, orthogonal rotation process that maximizes the sum of the variances of the squared loadings.

\section{References}

Adland, R. and Koekebakker, S. (2007) Ship valuation using cross-sectional sales data: A multivariate non-parametric approach. Maritime Economics and Logistics 9(2): 105-118.

Albertijn, S., Bessler, W. and Drobetz, W. (2011) Financing shipping companies and shipping operations: A risk-management perspective. Journal of Applied Corporate Finance 23(4): 70-82.

Alizadeh, A. and Nomikos, N. (2009) Shipping Derivatives and Risk Management. Hampshire, UK: Palgrave Macmilllan.

Angele, J. (1996) Zur Einstellung der Statistik der Aktienmärkte. Wirtschaft und Statistik 1(1): 25-30.

Batchelor, R., Alizadeh, A. and Visvikis, I. (2007) Forecasting spot and forward prices in the international freight market. International Journal of Forecasting 23(1): 101-114.

Benmelech, E. and Bergman, N. (2011) Bankruptcy and the collateral channel. Journal of Finance 66(2): 337-378.

(C) 2013 Macmillan Publishers Ltd. 1479-2931 Maritime Economics \& Logistics $\quad$ Vol. 15, 1, 32-71 65 
Bessler, W., Drobetz, W. and Seidel, J. (2008) Ship funds as a new asset class: An empirical analysis of the relationship between spot and forward prices in freight markets. Journal of Asset Management 9(2): 102-120.

Bessler, W., Drobetz, W. and Tegtmeier, L. (2010) Schiffe als Anlageklasse für institutionelle Anleger. Absolutreport 9(3): 46-57.

Bessler, W., Drobetz, W. and Thies, S. (2007) Kapitalkosten. Enzyklopädisches Lexikon des Geld-, Bank- und Börsenwesens. Frankfurt am Main, Germany: Fritz Knapp Verlag.

Bleymüller, J. (1966) Theorie und Technik der Aktienkursindizes. Wiesbaden, Germany: Betriebswirtschaftlicher Verlag Dr Th. Gabler.

Brooks, C. and Kat, M. (2002) The statistical properties of hedge fund index returns and their implications for investors. Journal of Alternative Investments 5(2): 26-44.

Campbell, J. and Thompson, S. (2008) Predicting excess stock returns out of sample: Can anything beat the historical average? Review of Financial Studies 21(4): 1509-1531.

Clarkson Research Services Ltd. (2008) KG Finance \& Shipping 2008. London: Clarkson Research Services.

Cullinane, K. and Gong, X. (2002) The mispricing of transportation initial public offerings in the Chinese Mainland and Hong Kong. Maritime Policy and Management 29(2): 107-118.

Drobetz, W., Schilling, D. and Tegtmeier, L. (2010) Common risk factors in the returns of shipping stocks. Maritime Policy and Management 37(2): 93-120.

Drobetz, W., Tegtmeier, L. and Topalov, M. (2008a) Handelsplattformen für Schiffsbeteiligungen: Analyse und Vergleich von Zweitmärkten für Schiffsbeteiligungen unter Effizienzgesichtspunkten. Finanz Betrieb 10(1): 57-67.

Drobetz, W., Tegtmeier, L. and Topalov, M. (2008b) Bewertung von Kommanditanteilen geschlossener Schiffsfonds mit dem Ertragswertverfahren. Finanz Betrieb 10(6): 399-411.

Engle, C. (1996) The forward discount anomaly and the risk premium: A survey of recent evidence. Journal of Empirical Finance 3(2): 123-192.

Esty, B. and Sheen, A. (2010) Compass Maritime Services LLC: Valuing Ships, Case Study, Boston: Harvard Business School.

Fama, E. (1984) Forward and spot exchange rates. Journal of Monetary Economics 14(3): 319-338.

Feri EuroRating Services AG. (2009) Feri Gesamtmarktstudie der Beteiligungsmodelle 2009. Bad Homburg, Germany: Feri EuroRating Services AG.

Friedrichs, R., Wegner, C. and Richter, T. (2007) Eigenkapitalfinanzierung über geschlossene Schiffsfonds. In: H. Winter, C. Henning and M. Gerhard (eds.) Grundlagen der Schiffsfinanzierung. Frankfurt am Main, Germany: Bankakademie-Verlag, pp. 851-892.

Getmansky, M., Lo, A.W. and Makarov, I. (2004) An econometric model of serial correlation and illiquidity in hedge fund returns. Journal of Financial Economics 74(3): 529-609.

Glen, D.R. and Martin, B.T. (2005) A survey of the modelling of dry bulk and tanker markets. In: K. Cullinane (ed.) Research in Transportation Economics Volume 12, Shipping Economics Amsterdam, The Netherlands: Elsevier, pp. 19-65.

Goyal, A. and Welch, I. (2008) A comprehensive look at the empirical performance of equity premium prediction. Review of Financial Studies 21(4): 1455-1508.

Grammenos, C. and Arkoulis, A. (1999) The long-run performance of shipping initial public offerings. International Journal of Maritime Economics 1(1): 71-93.

Grammenos, C. and Arkoulis, A. (2002) Macroeconomic factors and international stock returns. International Journal of Maritime Economics 4(1): 81-99.

Grammenos, C., Alizadeh, A. and Papapostolou, N. (2007) Factors affecting the dynamics of yield premia on shipping seasoned high yield bonds. Transportation Research Part E 43(5): 549-564.

Grammenos, C., Nomikos, N. and Papapostolou, N. (2008) Estimating the probability of default for shipping high yield bond issues. Transportation Research Part E 44(6): 1123-1138.

Grelck, M., Prigge, S., Tegtmeier, L. and Topalov, M. (2009) Diversification properties of investments in shipping. Journal of Alternative Investments 12(1): 55-74.

66 (C) 2013 Macmillan Publishers Ltd. 1479-2931 Maritime Economics \& Logistics Vol. 15, 1, 32-71 
Haralambides, H.E., Tsolakis, S.D. and Cridland, C. (2005) Econometric modelling of newbuilding and secondhand ship prices. In: K. Cullinane (ed.) Research in Transportation Economics Volume 12, Shipping Economics Amsterdam, The Netherlands: Elsevier, pp. 65-105.

Jolliffe, I.T. (2010) Principal Component Analysis, 2nd edn. New York: Springer.

Kavussanos, M., Juell-Skielse, A. and Forrest, M. (2003) International comparison of market risks across shipping-related industries. Maritime Policy and Management 30(2): 107-122.

Kavussanos, M. and Tsouknidis, D. (2010) The Determinants of Bond Spreads in the Global Shipping Industry. Athens University of Economics and Business. Working Paper.

Kavussanos, M., Visvikis, I. and Menachof, D. (2004) The unbiasedness hypothesis in the freight forward market: Evidence from cointegration tests. Review of Derivatives Research 7(3): 241-266.

Kavussanos, M.G. and Visvikis, I.D. (2006) Derivatives and Risk Management in Shipping. London: Witherbys Publishing.

Lambertides, N. and Louca, C. (2008) Ownership structure and operating performance: Evidence from the European maritime industry. Maritime Policy and Management 35(4): 395-409.

Leggate, H.K. (2000) A European perspective on bond finance for the maritime industry. Maritime Policy and Management 27(4): 353-362.

Lintner, J. (1965) The valuation of risk assets and the selection of risky investments in stock portfolios and capital budgets. Review of Economics and Statistics 47(1): S.13-S.37.

Lo, A.W. (2002) The statistics of Sharpe ratios. Financial Analysts Journal 58(4): 36-52.

Maritime Services. (2009) IFSL research, http://www.ifsl.org.uk, accessed June 2010.

Merikas, A., Gounopoulos, D. and Nounis, C. (2009) Global shipping IPOs performance. Maritime Policy and Management 36(6): 481-505.

Merikas, A., Gounopoulos, D. and Karli, C. (2010) Market performance of US-listed shipping IPOs. Maritime Economics and Logistics 12(1): 36-64.

Mossin, J. (1966) Equilibrium in a capital market. Econometrica 34(4): 768-783.

Randoy, T., Down, J. and Jenssen, J. (2003) Corporate governance and board effectiveness in maritime firms. Maritime Economics and Logistics 5(1): 40-54.

Schmitz-Esser, V. (2001) Aktienindizes im Portfoliomanagement: Funktionen, Merkmale und Indexeffekte. Bad Soden/Ts, Germany: Uhlenbruch Verlag.

Sharpe, W.F. (1964) Capital asset prices: A theory of market equilibrium under conditions of risk. Journal of Finance 19(3): 425-442.

Stopford, M. (2009) Maritime Economics, 3rd edn. New York: Routledge.

Syriopoulos, T. and Roumpis, E. (2009) Asset allocation and value at risk in shipping equity portfolios. Maritime Policy and Management 36(1): 57-78.

Syriopoulos, T. and Theotokas, I. (2007) Value creation throuh corporate destruction? Corporate governance in shipping takeovers. Maritime Policy and Management 34(3): 225-242.

Tegtmeier, L. and Topalov, M. (2006) Die Bedeutung von Schiffsbeteiligungen im Rahmen der Asset Allocation von Privatanlegern. Finanz Betrieb 8(7-8): S.506-S.509. 
$\infty$ Appendix A

Table A1: Results of market model regressions

\begin{tabular}{|c|c|c|c|c|c|c|c|c|c|c|}
\hline & \multirow[t]{2}{*}{ Observation period } & \multirow[t]{2}{*}{$\begin{array}{l}\text { MV Mio. USD } \\
31 \text { Dec. } 2007\end{array}$} & \multicolumn{2}{|c|}{$\begin{array}{l}\text { Descriptive } \\
\text { statistics }\end{array}$} & \multicolumn{6}{|c|}{$\begin{array}{l}\text { Regression } \\
\text { results }\end{array}$} \\
\hline & & & Mean & $S D$ & $\alpha_{i}$ & $t$-statistics & $\beta_{i}$ & t-statistics & $R^{2}$ & Adj. $R$ \\
\hline \multicolumn{11}{|l|}{ Container } \\
\hline Alexander \& Baldwin & January 1996-December 2007 & 2145.12 & 0.0083 & 0.0628 & 0.0047 & 0.93 & $0.53^{* * *}$ & 4.25 & 0.11 & 10.11 \\
\hline AP Moeller Maersk A & January 1996-December 2007 & 38719.87 & 0.0121 & 0.0962 & 0.0042 & 0.59 & $1.15^{* * *}$ & 6.47 & 0.23 & 30.22 \\
\hline AP Moeller Maersk B & January 1996-December 2007 & 38719.87 & 0.0120 & 0.0995 & 0.0034 & 0.46 & $1.26^{\star * *}$ & 6.98 & 0.26 & $5 \quad 0.25$ \\
\hline China Shipping Container Lines & June 2004-December 2007 & 4118.67 & 0.0254 & 0.1613 & 0.0031 & 0.12 & $1.95^{*}$ & 1.94 & 0.09 & 0.06 \\
\hline $\begin{array}{l}\text { Compania Sud Americana } \\
\text { De Vapores S.A }\end{array}$ & January 1996-December 2007 & 1870.36 & 0.0102 & 0.0972 & 0.0066 & 0.81 & $0.53^{* * *}$ & 2.66 & 0.05 & $5 \quad 0.04$ \\
\hline Evergreen Marine & January 1996-December 2007 & 1686.54 & 0.0029 & 0.1270 & -0.0026 & -0.25 & $0.81 * * *$ & 3.12 & 0.06 & 50.06 \\
\hline Finnlines & January 1996-December 2007 & 845.71 & 0.0105 & 0.0901 & 0.0054 & 0.75 & $0.73^{* * *}$ & 4.07 & 0.11 & $1 \quad 0.10$ \\
\hline Hanjin Shipping Co. Ltd & January 1996-December 2007 & 1941.23 & 0.0096 & 0.1851 & -0.0009 & -0.06 & $1.53 * * *$ & 4.15 & 0.11 & $1 \quad 0.10$ \\
\hline Heung-A Shipping Co. Ltd & January 1996-December 2007 & 45.27 & 0.0090 & 0.2356 & -0.0037 & -0.19 & $1.85^{* * *}$ & 3.90 & 0.10 & 0.09 \\
\hline Hyundai Merchant Marine Co. Ltd & January 1996-December 2007 & 2904.72 & 0.0082 & 0.2136 & -0.0096 & -0.60 & $2.58^{* * *}$ & 6.52 & 0.23 & $3 \quad 0.23$ \\
\hline Kawasaki Kisen (K-Line) & January 1996-December 2007 & 9343.70 & 0.0086 & 0.1147 & 0.0040 & 0.42 & $0.67 * * *$ & 2.85 & 0.05 & 0.05 \\
\hline MISC Berhad & January 1996-December 2007 & 10915.79 & 0.0083 & 0.0815 & 0.0041 & 0.61 & $0.61^{* * *}$ & 3.71 & 0.09 & 0.08 \\
\hline Mitsui OSK Lines (MOL) & January 1996-December 2007 & 19392.24 & 0.0108 & 0.1075 & 0.0060 & 0.67 & $0.71^{* * *}$ & 3.22 & 0.07 & 0.06 \\
\hline Neptune Orient Lines (NOL) & January 1996 - December 2007 & 4876.87 & 0.0096 & 0.1368 & -0.0015 & -0.15 & $1.62^{* * *}$ & 6.37 & 0.22 & 0.22 \\
\hline $\begin{array}{l}\text { Nippon Yusen Kabushiki Kaisha } \\
\text { (NYK) }\end{array}$ & January 1996-December 2007 & 12003.18 & 0.0038 & 0.0848 & 0.0014 & 0.19 & $0.36^{* *}$ & 2.02 & 0.03 & 30.02 \\
\hline Orient Overseas Intl & January 1996-December 2007 & 6115.37 & 0.0213 & 0.1245 & $0.0189^{*}$ & 1.79 & 0.35 & 1.33 & 0.01 & 0.01 \\
\hline Regional Container Line (RCL) & January 1996-December 2007 & 671.33 & 0.0099 & 0.1603 & 0.0027 & 0.20 & $1.06^{* * *}$ & 3.23 & 0.07 & 0.06 \\
\hline Samudera Shipping Line & October 1997-December 2007 & 119.47 & 0.0094 & 0.1611 & $6.25 \mathrm{E}-05$ & 0.00 & $1.53^{* * *}$ & 4.59 & 0.15 & 0.14 \\
\hline Sinotrans Ltd & February 2003-December 2007 & 1534.84 & 0.0090 & 0.0938 & -0.0087 & -0.64 & $1.20^{* *}$ & 2.60 & 0.11 & 0.09 \\
\hline Trailer Bridge Inc & July 1997-December 2007 & 152.59 & 0.0008 & 0.1902 & -0.0023 & -0.13 & 0.57 & 1.39 & 0.02 & 0.01 \\
\hline
\end{tabular}




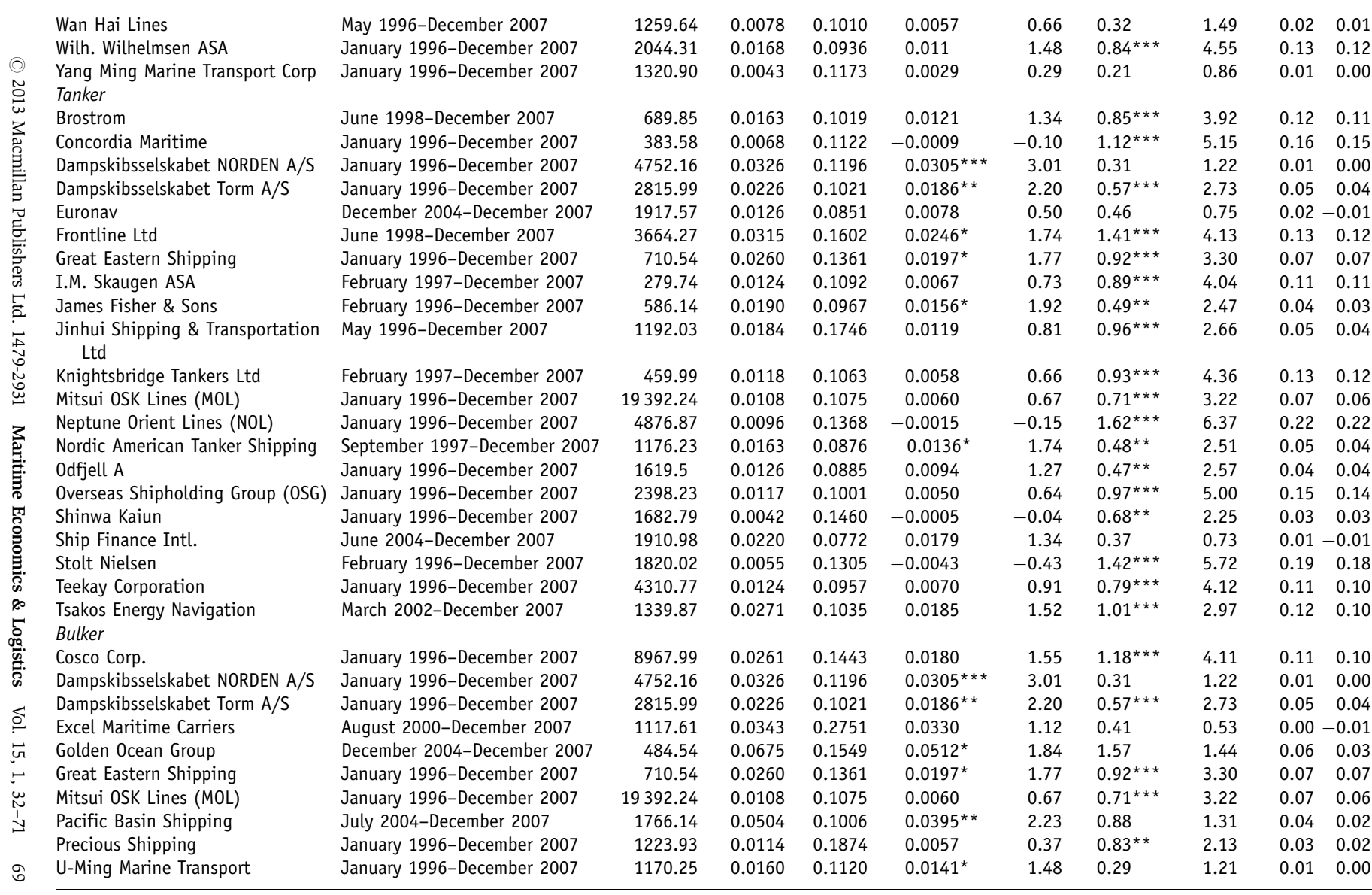


○े Table A1 continued

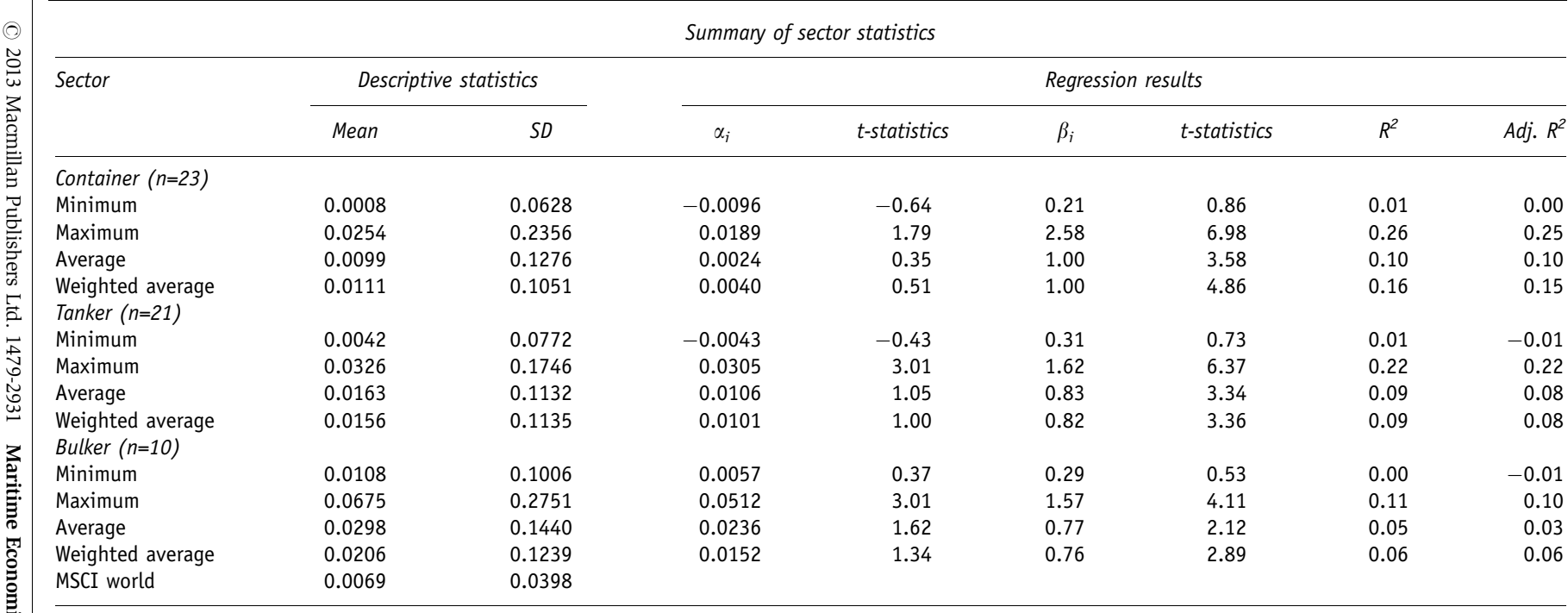

Means and Standard Deviation (SD) are based on logarithmic monthly returns. Regression results are for a market model of the form: $R_{i t}-R_{F t}=\alpha_{i}+\beta_{i}\left(R_{M t}-R_{F t}\right)+\varepsilon_{i t}$ where $R_{i t}$ is the stock return of shipping company $i$ at time $t, R_{F t}$ is the risk-free rate at time $t, R_{M t}$ is the return on the market portfolio (MSCI World index) at time $t$ and $\varepsilon_{i t}$ is a white-noise term. The table reports the estimated intercept term $\left(\alpha_{i}\right)$ and the beta coefficient $\left(\beta_{i}\right)$ for each firm $i .{ }^{*}$, ${ }^{* *},{ }^{* *}$ denote a 10 per cent, 5 per cent and 1 per cent level of significance. 


\section{Appendix B}

Table B1: Summary of one-ship companies contained in the KG index

\begin{tabular}{|c|c|c|c|c|}
\hline Equity house & $\begin{array}{l}\text { Total number } \\
\text { of } K G \text { funds }\end{array}$ & $\begin{array}{l}\text { Number of } K G \\
\text { funds with partly } \\
\text { available data }\end{array}$ & $\begin{array}{l}\text { Number of } K G \\
\text { funds included } \\
\text { in the index }\end{array}$ & $\begin{array}{c}\text { Percentage of } \\
\text { funds contained } \\
\text { in the index }\end{array}$ \\
\hline Atlantic & 34 & 26 & 26 & 100.00 \\
\hline BS Invest & 7 & 4 & 0 & 0.00 \\
\hline Castor & 31 & 7 & 0 & 0.00 \\
\hline CFB-Fonds & 12 & 4 & 0 & 0.00 \\
\hline Conti & 79 & 40 & 0 & 0.00 \\
\hline Dr Peters & 75 & 58 & 0 & 0.00 \\
\hline $\begin{array}{l}\text { EEH Elbe } \\
\text { Emissionshaus }\end{array}$ & 6 & 0 & 0 & 0.00 \\
\hline $\begin{array}{l}\text { Emissionshaus } \\
\text { FHH Fondshaus Hamburg }\end{array}$ & 32 & 24 & 24 & 100.00 \\
\hline GEBAB & 103 & 62 & 0 & 0.00 \\
\hline GHF & 67 & 24 & 0 & 0.00 \\
\hline Hamburgische Seehandlung & 20 & 15 & 0 & 0.00 \\
\hline Hannover Leasing & 3 & 2 & 0 & 0.00 \\
\hline Hansa Hamburg Shipping & 33 & 22 & 21 & 95.45 \\
\hline Hansa Mare & 20 & 20 & 0 & 0.00 \\
\hline Hansa Treuhand & 98 & 74 & 0 & 0.00 \\
\hline $\mathrm{HCI}$ & 509 & 262 & 60 & 22.90 \\
\hline Ideenkapital & 10 & 8 & 7 & 87.50 \\
\hline $\mathrm{KGAL}$ & 8 & 2 & 0 & 0.00 \\
\hline König \& Cie. & 49 & 28 & 0 & 0.00 \\
\hline Lloyd Fonds & 66 & 42 & 40 & 95.24 \\
\hline MPC & 92 & 45 & 35 & 77.78 \\
\hline Nordcapital & 89 & 60 & 57 & 95.00 \\
\hline Norddeutsche Vermögen & 96 & 48 & 40 & 83.33 \\
\hline Nordkontor & 8 & 4 & 0 & 0.00 \\
\hline Ownership & 21 & 2 & 0 & 0.00 \\
\hline PCE Premium Capital & 11 & 9 & 0 & 0.00 \\
\hline Salamon & 13 & 13 & 13 & 100.00 \\
\hline Vega Reederei & 22 & 22 & 0 & 0.00 \\
\hline Total & 1.614 & 927 & 323 & 34.84 \\
\hline
\end{tabular}

